Teología y Vida, Vol. XLVI (2005), 439 - 483

Agustina Serrano P.

Facultad de Teología

Pontificia Universidad Católica de Chile

\title{
La racionalidad apasionada. Acercamiento a la relación razón y amor en la obra "Camino de Perfección" de Santa Teresa de Ávila (1515-1582)
}

\section{INTRODUCCIÓN}

El presente estudio pretende ayudar a detectar la racionalidad teológica de Teresa desde la relación razón y amor en su obra "Camino de perfección". En él se comienza a descubrir la propia sistematicidad del pensar de esta autora y algunos destellos de la recepción de Gregorio, Escoto Eriúgena e Hildegarda de Bingen. Se reconoce la ingente producción escrita que existe y la necesidad de seguir profundizando.

\section{APUNTES CONTEXTUALES}

\section{Autora y contexto}

Santa Teresa de Ávila es una de las grandes figuras de la mística del Siglo de Oro Español. Su pensamiento, difícil de encuadrar, está entre el final de la Edad Media y el comienzo del Renacimiento. En los estudios sobre su obra está más desarrollada la espiritualidad que el pensamiento sistemático.

Con la base eclesiológica del Concilio Vaticano II, Pablo VI la declara Doctora de la Iglesia el 27 de septiembre de 1970, para saldar una deuda histórica y dar validez universal a su mensaje. Es el primer doctorado concedido por el magisterio eclesiástico a una mujer (1). Rahner afirma que este acontecimiento supera la actitud de no conferir el doctorado a mujeres por razones de valoración histórica y cultural. Este hecho supone que el puesto y la función de la mujer en la Iglesia quedaron afectados cuando se declaró a Santa Teresa Doctora de la Iglesia (2).

(1) Cf. Ros García, S., "Los estudios teresianos: panorama de actualidad y perspectivas de tratamiento": Teresianum 38/2 (1987) 149-209 (152).

(2) Cf. Rahner, K. "La experiencia personal de Dios más apremiante que nunca": Revista de Espiritualidad 29 (1970) 310-313 (310). 
Para entender lo que Teresa vivió, escribió y transmitió hay que realizar un triple acceso: histórico, literario y doctrinal.

Teresa critica en Camino la honra (CV 2, 6) y los linajes o sangre limpia (CV $22,4)$. Instaura el trabajo manual para todas las monjas. Tiene cierta predilección por el sector social medio (3). Desde su condición de mujer, asumida y vivida, es solidaria y se compromete con la sociedad de su tiempo; con la Iglesia que ve amenazada; y con su comunidad que desea reformar.

Une la conciencia de sus limitaciones con la audacia de su vocación haciendo un cierto uso del recurso a la inferioridad $(\mathrm{CV} \mathrm{1,2)}(4)$, para no levantar sospechas. En el siglo XVI no es fácil ser mujer, espiritual, lectora apasionada, etc. Teresa combate el monopolio de la cultura por los varones y reclama la presencia activa de la mujer en la Iglesia (CV, pról 3) (5), pidiendo el derecho a la vida espiritual: "no desechar ánimos virtuosos y fuertes aunque sean de mujeres" (CE 4, 1) (6). Esta página de Camino, se ha comentado bastante, tiene incluso una "historia azarosa y casi dramática, debido sin duda al insólito feminismo de la autora y al antifeminismo de sus primeros lectores, censores y editores. /.../ Hubieron de pasar siglos (1833) hasta que el famoso texto teresiano viese la luz por primera vez" (7). Se

(3) Cf. Ros, S., "Los estudios..." 173.

(4) CV 1, 2. /... Y Y como me vi mujer y ruin e imposibilitada de aprovechar en lo que yo quisiera en el servicio del Señor, y toda mi ansia era, y aún es, que pues tiene tantos enemigos y tan pocos amigos, que esos fuesen buenos, determiné a hacer eso poquito que era en mí, que es seguir los consejos evangélicos con toda la perfección que yo pudiese, y procurar que estas poquitas que están aquí hiciesen lo mismo, confiada en la gran bondad de Dios que nunca falta de ayudar a quien por él se determina a dejarlo todo; /.../.

(5) Pról 3. Sé que no falta el amor y deseo en mí para ayudar en lo que yo pudiere para que las almas de mis hermanas vayan muy adelante en el servicio del Señor; y este amor, junto con los años y experiencia que tengo de algunos monasterios, podrá ser aproveche para atinar en cosas menudas más que los letrados que, por tener otras ocupaciones más importantes y ser varones fuertes, no hacen tanto caso de cosas que en sí no parecen nada, y a cosa tan flaca como somos las mujeres todo nos puede dañar, porque las sutilezas del demonio son muchas para las muy encerradas, que ven son menester armas nuevas para dañar. Yo, como ruin, heme sabido mal defender, y así querría escarmentasen mis hermanas en mí. No diré cosa que en mí, o por verla en otras, no la tenga por experiencia.

(6) CE 4, 1. Parece atrevimiento pensar /.../. Pues no sois Vos, Criador mío, desagradecido para que piense yo daréis menos de lo que os suplican, sino mucho más; ni aborrecisteis, Señor de mi alma, cuando andabais por el mundo, las mujeres, antes las favorecisteis siempre con mucha piedad. Lo que viene a continuación es lo tachado y suprimido en el códice de Valladolid, y bien merece la pena leerlo: y hallasteis en ellas tanto amor y más fe que en los hombres, /.../. ¿No basta, Señor, que nos tiene el mundo acorraladas e incapaces para que no hagamos cosa que valga nada por Vos en público ni osemos hablar algunas verdades que lloramos en secreto, sino que no nos habíais de oír petición tan justa? No lo creo yo, Señor, de vuestra bondad y justicia, que sois justo juez, y no como los jueces del mundo, que como son hijos de Adán y, en fin, todos varones, no hay virtud de mujer que no tengan por sospechosa.

Sí, que algún día ha de haber, Rey mío, que se conozcan todos. No hablo por mí, que ya tiene conocido el mundo mi ruindad, y yo holgado que sea pública, sino porque veo los tiempos de manera que no es razón desechar ánimos virtuosos y fuertes, aunque sean de mujeres. /.../. Se tachan expresiones críticas, audaces y hasta temerarias. Pasa del siguiente modo a CV 3, 7. "Parece atrevimiento pensar /.../. Pues no sois Vos, Criador mío, desagradecido para que piense yo dejaréis de hacer lo que os suplican; ni aborrecisteis, Señor, cuando andabais en el mundo, las mujeres, antes las favorecisteis siempre con mucha piedad. /.../"

(7) Álvarez, T., "Santa Teresa y las mujeres en la Iglesia. Glosa al texto teresiano de Camino 3". Monte Carmelo 89 (1981) 121-132, (121). 
valora el libro como ejercicio de protesta social y defensa de la mujer (8). En efecto se afirma que este libro es fuertemente polémico respecto a tres puntos concretos, íntimamente unidos entre sí: el tema de la mujer (pról 3; CE 4, 1; CE 48, 2//CV 28, 10); los libros (CE 35, 4//CV 21, 3; CE 36, 4; 73, 4); y la oración (CV 21) (9). La reforma de Teresa no sigue los cauces de Trento que propugna Roma, sino que engancha con corrientes reformistas castellanas anteriores a Lutero y potenciadas por el Rey. Esto le hace crear monasterios reducidos, acogedores, sin diferencias, con comunicación de bienes y clausura estricta (10).

A nivel literario, su lenguaje es tierno, amoroso, claro y duro; pero nunca resentido, ni dolorido. Es un lenguaje racional y apasionado. Teresa observa lo que pasa en su entorno cultural y literario. Vive en una época en que se "literaturizaba" la vida y se vivía la literatura. Ella vive en un tiempo de formación de la lengua castellana; tiene clara pretensión de ser leída; y se alegra cuando consigue expresar su idea; además busca ampliar el lenguaje y sus expresiones. Es una mujer inteligente y culta, cosa poco común en su tiempo; no tiene formación sistemática, pero sí una apasionada afición a la lectura desde niña, que le lleva a tomar decisiones vitales. Se pueden seguir tres fuentes de información para conocer sus lecturas: lo que ella dice en sus obras "Vida" y "Moradas"; lo que debe haber en los conventos (Constituciones 8); y lo que ella leía (11).

El pensar racional amoroso conduce a Teresa a defender apasionadamente la humildad, la pobreza, lo pequeño, lo cotidiano. Con ella se proclama el doctorado de la experiencia. Se le reconoce su mérito en la pelea por el derecho a la oración como relación personal amistosa, en la que es necesario el conocimiento para el amor. Esta relación la va mostrando de modo pedagógico en el "Camino". En la oración acontece la revelación de Dios y la del hombre: "la comunicación de Dios que le infunde amor y conocimiento /.../ de muchas maneras se da a conocer conforme al deseo que tengamos de verle" (CV 34, 13) (12). La Biblia es su mayor fuente de inspiración, sus lecturas favoritas eran muy ricas en citas bíblicas. Con los libros bíblicos se contrasta y en ellos encuentra el criterio de verdad (CV 21,4).

Teresa expresa una incansable búsqueda de Dios como lo permanente, lo que ha de durar por siempre. Ella tiene certeza de la presencia cercana y gratuita de Dios que le lleva a formular una antropología con primacía de la gracia. La humanidad de Cristo es el salvoconducto en toda la andadura de fe, no concibe sin Él su existir; y la pretensión del desposorio es la meta para vivir y morir. Lo ha sabido defender frente a los teólogos de su tiempo: nada sin Cristo. Su modo de vivir y relacionarse

(8) Cf. De Pablo Maroto, D., "Santa Teresa de Jesús. Camino de Perfección”. Editorial de Espiritualidad. $4^{a}$ edición, Madrid (1983) 49, 67.

(9) Cf. Herráiz, M., "Introducción al Camino de Perfección". Editorial Monte Carmelo, Burgos (2001) 46.

(10) Cf. Ros, S., "Los estudios..." 178.

(11) Cf. Vega García-Luengos, G., "La dimensión literaria de Santa Teresa": Revista de Espiritualidad, 41 (1982) 29-62. Este autor en las páginas 33 y 36 remite a dos obras: Vossler, K., "Lope de Vega y su tiempo". Madrid 1933, 209; y Morel-Fatio, A., "Les lectures de Sainte Thérèse, en Bulletin Hispanique 10 (1908) 17-67.

(12) Cf. Herráiz, M., "Introducción al Camino de Perfección". Editorial Monte Carmelo, Burgos (2001) $112,122$. 
es optimista, tiene un gran sentido práctico; es agradecida, alegre y con un gran sentido del humor. Este humanismo se refleja en sus escritos, sabe llegar a lo profundo del ser humano; porque se conoce invita a todos al mismo proceso de conocerse (13).

\section{La obra "Camino de Perfección"}

Camino de Perfección es la primera obra impresa de Santa Teresa, se imprime en Evora (Portugal) en el año 1583 a cargo de D. Teutonio de Braganza. Es su segunda gran obra, escrita en 1566, después de "Vida", quiere ser un libro guía para sus comunidades, que contiene el espíritu de la reforma (14).

La obra Camino tiene una génesis, una estructura y unos contenidos teológicos. Entre los estudiosos se presentan bastantes convergencias aunque también se expresan sus diferencias (15). Tomás Álvarez dirige la reproducción en facsímil, técnica-

(13) Cf. Ros, S., "Los estudios..." 206-207.

(14) Cf. De Pablo Maroto, D., "Santa Teresa. Comentario al Padre Nuestro". Editorial de Espiritualidad, Madrid (1982) 11.

(15) Cf. Martín del Blanco, M., "El Camino de perfección". En "Santa Teresa de Jesús: Mujer de ayer para el hombre de hoy". Editorial Mensajero, Bilbao (1975) 173-188. Cf. Efrén de la Madre de Dios, y Otger Steggink, "Santa Teresa de Jesús Obras completas". BAC, $8^{\text {a }}$ edición, Madrid (1986) 233-234. Cf. Herráiz, M., "Introducción al Camino de Perfección". Editorial Monte Carmelo, Burgos (2001). Cf. Aguado, J.Ma , "Santa Teresa de Jesús. Camino de perfección". Ediciones La Lectura, Madrid (1929) 11-48.

Para Martín del Blanco la génesis de la obra es la siguiente: la primera redacción y la censura (El Escorial) en el año 1566. La segunda redacción, el autógrafo de Valladolid, es una "elaboración meticulosa, llevada a cabo con tesón y meticulosidad", cuidando con sobriedad lo doctrinal y dividiendo la obra en capítulos (178), en la segunda mitad del 1566. Se hacen muchas copias, algunas de ellas revisa Teresa. La estructura de Camino de Perfección (Valladolid) consta de una parte introductoria cuyo contenido central es la razón eclesial de la vida contemplativa: contemplación-acción (capítulos 1-3); luego una parte Primera que trata la necesidad de la práctica de las virtudes para la vida espiritual, fundadamente radicada (capítulos 4-16); y la parte Segunda desde el capítulo 16, 5 hasta el último capítulo 42, que trata de la práctica de la oración, en un doble tiempo: de la oración en general (capítulos 16-26) y un modo práctico de orar, siguiendo el Padre Nuestro (27-42). La doctrina se sintetiza en tres tesis fundamentales: la primera resalta la función eclesial y el valor santificante de la vida contemplativa; la segunda tesis es la absoluta necesidad de intensa y adecuada ascesis para poder cultivar normalmente la vida contemplativa; y la tercera es la progresiva evolución de la oración prácticamente cultivada. Esto lo expone Teresa con argumentos doctrinales y con alegorías (182-185). Dentro de los temas doctrinales, señalar uno de los que el autor recoge, la relación entre oración y virtudes, y que presenta un breve apunte de la antropología unitaria de Teresa. Ella elige tres elementos: el amor que hace referencia a nuestra relación con los demás; la humildad en relación a Dios; y el desasimiento para la relación con nosotros mismos. Además cada una de ellas alude a la vida afectiva (amor), la intelectual (humildad, autoestima) y la corporal (pobreza). Los tres ejes del ser humano se pueden sintetizar de este modo: en la persona se vive de modo global el amor y la razón.

Para Efrén de la Madre de Dios, y Otger Steggink la primera redacción, el manuscrito de El Escorial, lo escribe Teresa entre 1562 y 1564; la segunda redacción, el manuscrito de Valladolid, en el 1569. Ellos dan cuenta de tres copias: la de Salamanca, la de Madrid y la de Toledo. La edición de Evora, sale en 1583 sobre la redacción de Valladolid con "mano y cabeza de hombre", se guarda en las carmelitas descalzas de Toledo. La estructura de El Escorial la organizan en tres bloques: fin de la Orden, en los capítulos 1 al 4; medios para alcanzarlo: la oración, en el capítulo 5; y el último apartado consta de dos partes: las disposiciones morales (6-23); y la técnica para su ejercicio (24-73).

Maximiliano Herráiz sitúa la fecha de composición en 1566. El contenido es la oración, como elemento esencial de la vocación, es un tratado de vida espiritual. La estructura interna tiene 
mente perfecta del autógrafo de Valladolid. Se fija la datación de las dos redacciones de la obra. Se clarifica la naturaleza de la tercera redacción de la obra (manuscrito de Toledo). Álvarez defiende: "la continuidad de las dos redacciones, dentro del mismo año 1566, a distancia de pocos meses: a partir de enero o febrero, la redacción primera; hacia verano o principio de otoño, la segunda" (16).

Camino de Perfección es un itinerario de conversión personal, comunitaria y estructural; recorrido con una determinada "racionalidad apasionada" que desenmascara todo lo que no está al servicio del Reino. En esta obra se va mostrando el camino de la perfección posible para cada uno y para todos; no es selectivo, aunque sí tremendamente radical. Camino plantea una estrategia que se logra desde el campo del saber, las letras, la reflexión, el estudio y el conocimiento; en íntima unión con el amor, el querer, el desear, y el consentir con determinada determinación. Teresa en este camino va llevando progresivamente al lector, a sus hermanas, a la Reforma; hacia un objetivo. En la travesía analiza, informa, critica; para reconducir todo hacia la meta: la perfección. Perfección, plenitud que se va regalando amorosamente cuando se conoce el camino estrecho de la humildad y el desasimiento. Desde el amor que experimenta se siente segura para ironizar, criticar, demoler una racionalidad esclavizadora (17).

La obra "Camino de perfección" constituye todo un arte literario que refleja la fogosidad y el ardiente deseo de esta escritora de quedar en la memoria. A Teresa le vino bien la orden-mandato de escribir; el obedecer encauzó su necesidad de comunicarse, y permitió no ser tachada de atrevida. En Camino ella manifiesta su interés y su vocación de escritora (18). El tipo de lenguaje que utiliza ha creado bastante polémica. La situación actual se puede situar de este modo: unos autores defienden

cuatro partes: la gran empresa del Carmelo (1-3, "empresa que pretendemos ganar" CV 4, 1); los presupuestos de la oración o virtudes (4-25, "cosas necesarias para los que pretenden llevar camino de oración" CV 4, 3); la naturaleza y el desarrollo de la oración, con sus exigencias (2635, "todo el modo de oración ... desde los principiantes a la oración mental, y de quietud y unión" CV 37, 1); los efectos de la contemplación (36-42, "Ahora comienza ya el Señor a darnos a entender los efectos que deja, cuando son mercedes suyas" CV 37, 1) (25-39).

La obra de José María Aguado también se manejó, por curiosidad respecto a la fecha de su publicación, 1929, y los comentarios que hace en su introducción. Respecto a la Génesis habla de dos autógrafos, el de el Escorial y el de Valladolid, y de tres copias, la salmantina, madrileña y toledana hacia el 1571. En relación al título recoge los siguientes: "Camino de oración", "Camino de contemplación", "Camino de perfección", "El Padrenuestro".

(16) Cf. Álvarez, T., "Santa Teresa de Jesús. Camino de Perfección". Tipografía Políglota Vaticana, vol. 2, Roma (1965) 103. De esta misma opinión es De Pablo Maroto, D., "Camino de Perfección". En "Introducción a la lectura de Santa Teresa". Editorial de Espiritualidad, Madrid (1978) 269-310.

(17) Ya se ha dicho como ella denuncia: la relación de las mujeres respecto a sus maridos, las mujeres en la Iglesia, las mujeres espirituales, la polémica entre oración vocal y mental, etc. El ser humano en su condición femenina, que es minusvalorada, es querida y amada por Dios que ve en ella gran fe y amor. Defiende ardientemente a la mujer desde una visión de lo global, estructural que crea condiciones antihumanas. Frente a lo cual hace su aporte, que siendo pequeño es germen de futuro y está fundamentado por la razón y el amor.

(18) Cf. Ros, S., "Los estudios..." 190-193. Le habían confiscado su primera obra "Vida", y quiere dejar un "a modo de" resumen de dicho escrito, cuando se decide a obedecer a su confesor, escribiendo Camino. Escribe para ser leída y por ello se autocensura; no quiere caer bajo sospecha, y sí captarse al destinatario. 
que Teresa se vulgariza y otros rechazan esta afirmación. Se trataría, más bien, de armonizar lo vulgar y coloquial, con lo culto y literario, en la obra de Teresa (19).

\section{Fuentes}

Es difícil descubrir quien influyó mayormente en el pensamiento de Teresa; ella cita a San Gregorio, San Agustín y San Jerónimo. Teresa asimila influencias de la élite (humanismo, la devotio moderna, la espiritualidad franciscana, el biblismo, ideas luteranas) y también de la tradición castellana (el gusto por las imágenes, los santos, los sermones, las procesiones, y la familiaridad permanente con la muerte).

Respecto a las fuentes se afirma que imita poco de sus lecturas para defender su originalidad; otros dicen que ella asimiló y sintetizó más de lo que inventó (20).

García Concha señala tres fuentes importantes. En primer lugar los confesores y teólogos: a) los franciscanos le aportan la entrega al amor de Dios y le ayudan en el análisis introspectivo, en el uso del lenguaje coloquial, en el recurso a imágenes, en las comparaciones en acumulación, etc.; b) los jesuitas le influyen tanto en la disciplina moral como en la intelectual; c) y en tercer lugar los dominicos potencian la voluntad de compromiso y apostolado. En un segundo nivel Teresa está influenciada por la predicación de la época, con los abundantes elementos retóricos de los sermones. Finalmente los tratados de espiritualidad.

En definitiva las lecturas configuran en Teresa su heroísmo, sus aires de epopeya, y la vida como lucha entre el bien y el mal (21). La gran fuente de inspiración teresiana es sin duda la Biblia, que ella llama "libro vivo". En Camino 21, 4 defiende la lectura de la Biblia, son "libros muy concertados", y con ellos se identifica. Lee los textos en lengua vernácula hasta el famoso Índice inquisitorial de Valdés de 1559, que ella denuncia apasionadamente (Vida 26, 6). Sus lecturas eran ricas en citas bíblicas como ya se ha indicado (las Confesiones de San Agustín ofrecen cerca de 600 citas, y las cartas de San Jerónimo, más de un millar de citas bíblicas). La

(19) Cf. Ros, S., "Los estudios..." 196. En un primer grupo de autores tenemos: Menéndez Pidal que defiende que ella usa el lenguaje corriente del habla hidalga es el "escribo como hablo"; Lázaro Carreter afirma que por prudencia ella se vulgariza, para no hacer ostentación de saber; Américo Castro indica que se hace rústica para igualarse con el castellano viejo; Lapesa también señala un fingimiento voluntario; Aurora Egido habla de la santa ignorancia como estrategia de combate contra los letrados. En un segundo grupo tenemos: García Concha que lo atribuye a inseguridad de la escritora, los arcaísmos y rusticismos pertenecen al acerbo común del habla literaria del siglo XVI; Tomás Álvarez y Ninfa Watt rechazan una vulgarización intencionada; Germán Vega García-Luengos afirma que las incorrecciones son las normales del habla y también de la escritura de la época.

(20) Cf. Vega García-Luengos, G., "La dimensión..." 34. Entre los autores que citan sus fuentes se dice que Teresa leyó mucho y bien, y lo singular está en la vivencia asimilada de todos los recursos, ella asume y crea. Las Obras que Teresa utiliza son: "Epístolas de San Jerónimo" (Vida 3, 7); "Moralia in Job" de San Gregorio (Vida 5, 8); "El Tercer abecedario" de Osuna (Vida 4, 7); "Las Confesiones" de San Agustín (Vida 9, 8); "Subida al Monte Sión" de Bernardino Laredo (Vida 23, 12); Los libros de la Biblia (Salmos, Cantar de los Cantares, Evangelios, Cartas de Pablo, etc.); "La imitación de Cristo" de Kempis; "Vita Christi" (recopilatorio evangélico) de Ludolfo de Sajonia, el Cartujo (le acercan a la humanidad de Cristo); "Vía Spiritus" de Bernabé de Palma, influye en Teresa en el "cuadrar el entendimiento", y en la postura de que la humanidad de Cristo es mediadora para la vida espiritual.

(21) Cf. "El arte literario de Santa Teresa", Editorial Ariel, Barcelona (1978), 47-90 (49). 
Escritura tiene para ella un valor de contraste con sus vivencias, un carácter funcional; es criterio de verdad (22).

En Teresa se han podido detectar ciertas influencias de Gregorio de Nisa y de Juan Escoto Eriúgena desde el estudio realizado por J.A. Pachas (23), y también de Hildegarda de Bingen desde el trabajo realizado por A. Meis (24).

Algunos elementos de esta influencia se notan en relación a la visión de Dios (25). Al tratar el tema del conocimiento y del amor, Teresa siempre se preocupó de conocer y dar a conocer; y su aporte es que se conoce por la experiencia, lo cual supone un adelantamiento a su época. Dios siendo incognoscible se manifiesta y se "comprende y siente"; por eso es como un amor sin saber, es como un gozar sin abrasarse. Teresa lo incorpora como camino de ascenso, de deseo amoroso que lleva a la perfección para el encuentro con Dios (26).

Por otra parte, en la concepción antropológica, al tratar la inteligencia y la sensibilidad, Teresa anuncia el deseo de verse ya con Dios, la irremediable pasión por encontrase con el Amado. La necesidad de conocer para amar es fuego que va abrasando y es sed que no se sacia aunque se beba $(\mathrm{CV} 19,2)$. Ella tiene una concepción unitaria, igualitaria y global de todo lo humano: lo inteligible y lo sensible, lo masculino y lo femenino, prefiguran la unión entre Cristo y la Iglesia (Ef 5, 31-32) (27).

(22) Cf. Ros, S., "Panorama..." 205.

(23) Cf. Pachas, J.A., "Influencia de Gregorio de Nisa sobre Juan Escoto Eriúgena. Aproximación a partir del Periphyseon". Aporte al proyecto Dipuc 2001/II-15CE.

(24) Cf. Meis, A., "Racionalidad ardiente. Acercamiento a la relación razón y amor en la obra Scivias de Hildegard von Bingen". Aporte al proyecto Dipuc 2001/II-15CE.

(25) Cf. Pachas, J.A., "Influencia...". Antes que Juan Escoto Eriúgena, Gregorio ve a Dios como "fuente del bien" (Cf. Eun 107, 8); como "inexpresable con palabras y razonamientos" (Cf. Eun 266, 12-14; Cant 159, 6-7; 246, 8-10); como "incomprensible" por el sujeto humano (Cf. Cant 246, 5-8); pero a la vez Dios se presenta como el deseado (Cf. Cant 31, 5-8; 32, 5-8). Para Juan Escoto Eriúgena, Dios se "comprende y siente", se hace "visibilidad del invisible", y es "temporalidad de aquello que no tiene tiempo" (Cf. CCCM 163, 22, 589-598). La visión de Dios para Gregorio es no verlo, para Juan "la ignorancia sobre Dios es verdadera sabiduría" (Cf. CCCM 164, 48, 1277-1278). Dios es visto por Eriúgena como el amor (ágape): "causa de todo amor, se difunde en todas las cosas y recoge todas las cosas /.../ es término de los movimientos amorosos de toda criatura" (Cf. CCCM 161, 106, 3305-3307; y 107, 3329-3332). Del mismo modo lo vio Gregorio.

Cf. Meis, A., "Racionalidad ...". Se afirma que la racionalidad en su belleza creatural posee un "sentido de la razón" que se encuentra en el origen, en la gracia de Dios que insufló este sentido al crear al hombre (Sc III 2, 9/284). Hildegard explicita que hay un nexo significativo entre el sentir y la razón: el bien es obrado en el hombre de forma que "sintáis a través de la razón". Se da una complementariedad entre voluntad y razón. Esto acontece en las obras en que se discierne (Sc III 5, 32/735). En efecto, la autora detecta entre sentir y razón una relación tal que abre a la alabanza (Sc III 13, 16/572).

(26) Así se expresa en CV 25, 2. "Entiende que, sin ruido de palabras, le está enseñando este Maestro divino, suspendiendo las potencias, porque entonces antes dañarían que aprovecharían si obrasen. Gozan sin entender cómo gozan; está el alma abrasándose en amor, y no entiende cómo ama; conoce; que goza de lo que ama, y no sabe cómo lo goza; bien entiende que no es gozo que alcanza el entendimiento a desearle; abrázale la voluntad sin entender cómo; mas en pudiendo entender algo, ve que no es este bien que se puede merecer con todos los trabajos que se pasasen juntos por ganarle en la tierra. Es don del Señor de ella y del cielo, que en fin, da como quien es. Esta, hijas, es contemplación perfecta".

(27) Cf. Pachas, J.A., "Influencia...”. Respecto a la concepción antropológica, Gregorio y Juan Escoto ven al hombre como microcosmos e imagen de Dios. El hombre es cuerpo y alma, y está consti- 
En la cristología de Teresa se da una clara referencia a la kenosis de la razón por amor $(\mathrm{CV} 3,8)$. Es muy concreta y explícita: lo humano de Jesús es lo que la atrae y la convierte; su presencia es real $(\mathrm{CV} 28,11)$ y ella comprende su anonadamiento (CV 22,4), su entrega hasta la muerte por amor al hombre y por fidelidad al plan de Dios (CV 36, 5) (28).

Respecto al concepto de participación y retorno, en y a la verdad, bondad, y belleza de Dios; Teresa afirma que lo oculto se manifiesta cuando la persona "arde en deseo" (CV 27, 1; 28, 8); y también que la verdad, la bondad y la belleza de Dios siendo inefables, como el amor, se comparan con el fuego y el agua (CV 19, 4) en la imagen de la fuente (CV 20, 1); lo mismo cuando habla respecto a la esposa, el alma es fuente y agua que harta y quita la sed (CV 19,8), Cristo es la fuente que invita a beber de Él $(J n$ 7, 38) (29). A más contemplación más se

tuido también por carne, alma y espíritu. Por su carácter espiritual es racional y permite que actúe la gracia de Dios para llevarlo "por el éxtasis de la mente... hacia ... el rayo de la oscuridad divina". Para estos autores la imagen de Dios es el alma, y especialmente la inteligencia humana; hablan de la belleza de la mente que aspira a la belleza de Dios. Así, para Juan E. Eriúgena el alma cuando considera las cosas divinas se llama "mente, espíritu o intelecto", y cuando se relaciona con la creación es "razón discursiva" (Cf. CCCM 164, 20, 526-528). La gracia y la libertad conducen al hombre a lo mejor, y le inflaman "por el fuego del amor divino" (Cf. CCCM 164, 22, 578). Para Gregorio la gracia es un proceso; mejor, es el mismo Cristo.

Cf. Meis, A., "Racionalidad ...". Hildegarda de Bingen cuando habla de la racionalidad en su belleza creatural destaca que la razón es un elemento constitutivo del hombre con la función de enseñar y hacer entender (Sc I 4, 4/262), y su tarea es iluminar para realizar la obra (Sc I 4, 20/ 643). Además la razón es voz del alma que se manifiesta en el entendimiento y en la voluntad (Sc I 4, 23/708). La autora se detiene también en estudiar la unión que se opera entre la razón y los sentidos (Sc I 4, 24/726). La razón es modo originante en medio de los demás elementos constituyentes del ser creatural (Sc I 4, 26/764). Hildegard afirma que los que cumplen la voluntad de Dios manifiestan en sus semblantes la belleza de la razón (Sc I 6, 2/80). Del mismo modo existe una relación razón y voluntad (Sc I 6, 3/94); y ella muestra un desplazamiento de la belleza de la razón del orden creatural al encarnatorio (Sc III 2, 9/284). Además sitúa a la razón del hombre entre la disyuntiva del bien y el mal (Sc II 1,2/133): el hombre está ante un "bullir de deseos" entre los que ha de elegir y esto se muestra en la "ciencia de la razón" (Sc III 2, 12/353; 8, 8/ 470). Hildegarda afirma que los deseos más profundos de la razón se sintetizan en regresar junto a Dios (Sc II 5, 40/1222).

(28) Cf. Pachas, J.A., "Influencia...". Respecto a la visión de Cristo: Gregorio afirma que la creación ha sido hecha a imagen del Hijo; y Dios se revela de modo que el hombre lo puede entender, se conforma a la medida humana, se expresa de manera humana y asume sentimientos humanos. Para Juan E. Eriúgena el misterio de Dios se revela en el hombre Jesús, que aparece como logos, razón y causa de la creación; el Verbo se anonada y tras la muerte y resurrección asciende al cielo (Cf. CCCM 164, 8, 164-165).

Cf. Meis, A., "Racionalidad ...". En cristología Hildegard von Bingen va a tratar cómo la razón del ser humano es puesta en libertad por el amor redentor de Dios: al encarnarse la Palabra de Dios y porque la acción del Espíritu Santo enciende el "sentido de la razón" y no puede negar que conoce a Dios (Sc III 5, 31/722). Otro elemento es la obra salvífica del Hijo amado del Padre, esto lo pueden descubrir aquellos en cuya razón "medran determinados talentos" (Sc III 5, 31/ 722). En última instancia Jesucristo es la gracia que ilumina y alienta la confluencia entre razón y voluntad.

(29) Cf. Pachas, J.A., "Influencia...". Respecto a la participación, Gregorio defiende la participación por un descenso, una asimilación que es un proceso sin fin, ya que la felicidad no se detiene siempre va a más. En Juan Escoto la participación es reparto de los dones divinos de arriba abajo (Cf. CCCM 163, 18, 490-494). Ambos plantean la participación por la vía de los transcendentales del ser. Dios es deseable y los perfectos aspiran a Él sin detenerse. Para Gregorio los transcendentales se concretan en el amor, "siendo clave el deseo amoroso de la belleza divina" (Cf. Cant 23 , 17). Para Eriúgena el principal transcendental es la bondad que es invisible e inefable pero deviene en esplendor; para este autor la belleza de Dios no conoce saciedad, puesto que su deseo 
comprende que Dios es incomprensible; a más amor, goce, cercanía, menos se sabe cómo acontece (30).

Desde las conclusiones de los estudios de A. Meis y de J.A. Pachas se pueden sintetizar las siguientes aportaciones: 1. Teresa tiene una comprensión de Dios como transcendencia e incomprensibilidad que le hace ser el deseado. 2. Ella también entiende al hombre como imagen de Dios; cuya razón, al ser capaz y omniabarcante, puede comprenderse como "racionalidad sentiente". 3. Cristo es revelación de Dios en la carne y descenso divino, esto se concreta en la experiencia cercana de la encarnación y el anonadamiento que consigue restaurar el oscurecimiento de la razón por el amor liberador de Dios. 4. Finalmente Teresa habla de un camino que va de la unidad a la multiplicidad, y el retorno es la reunificación, acontece de la multiplicidad a la unidad. Se acerca a Gregorio en la imagen de la oscuridad para el mal y el pecado, y la luz para la salvación y el conocimiento humano. Se detectan conexiones con Hildegarda en que la plenitud de la racionalidad le proviene del amor abriéndole a la alteridad, que desemboca en el cántico amoroso.

\section{Estudio actual}

Se ha tratado de hacer un cierto acercamiento a los estudios doctrinales, y una pequeña selección de aquellas obras que abordan el tema con objetividad para no

va en aumento (Cf. CCCM 164, 117, 3501-3507). La imagen de la fuente tomada de Jn 4, 13-14; 7, 38 y 1 Cor 15,10 , es usada para explicar a Dios, a la esposa y a Cristo. Respecto a Dios, quien bebe se plenifica y no agota la fuente, es agua viva.

(30) Cf. Meis, A., "Racionalidad ...". Hildegarda en la III parte, cuando escribe respecto a las visiones 1-8 trata la plenificación de la razón por la gracia de Dios. Hay una referencia a la dimensión sacramental: el bautismo (Sc III 2, 9/293) y la penitencia (Sc III 5, 4/221 que permite levantarse al hombre si lo quiere por su raciocinio). Aparece también la dimensión eclesial (Sc III 6, 11/ 318). La razón es perfeccionada por la "gracia de Dios" que profundiza el "sentido de la razón". Se destaca la restauración como plenificadora de la razón en su constitución originaria. En segundo lugar Hildegarda da a entender cómo el afianzamiento de la gracia de Dios acontece por la razón. La gracia concedió la razón para obrar bien (Sc III 2, 10/331). La sabiduría está en el raciocinio humano para ejercer el magisterio y la misericordia. En tercer lugar se rescata la rectificación de la razón por la justicia. Esto se opera por la confluencia de la razón con la gracia que se consumará en la adoración (Sc III 8, 8/470).

Cf. Pachas, J.A., "Influencia...". Respecto al retorno, para Gregorio hay un ascenso gradual y progresivo del hombre y la creación, por un camino de purificación y divinización hasta que en el se alcanza la visión de Dios. Pero matizado porque no hay límite en la perfección y cada meta es el inicio de algo superior.

Cf. Meis, A., "Racionalidad ...". Se llega a la consumación de la racionalidad en la adoración. La racionalidad humana se perfecciona en el canto (Sc III parte). Trata la autora tres aspectos importantes. El canto perenne de la razón ardiente. Acá se descubre que toda la inteligencia racional devuelve con gozo todo lo recibido al Creador en la adoración (Sc III 2, 23/638). En efecto la racionalidad está en el alma junto con la ciencia y el entendimiento, y por esto el hombre tiene su fin último en la adoración en las entrañas (Sc III 4, 15/427). En definitiva, no es solo canto sino intensificación por la celebración que abarcando a todo el hombre lo constituye en alabanza. El segundo elemento que considera es que la alabanza amorosa racional conduce lo creacional hacia la restauración. Por la gracia la naturaleza se perfecciona, "el hombre redimido exultará cantando" en alabanza. En síntesis: se alaba a quien infundió la razón, es alabanza amorosa e inteligente posibilitada por la razón (Sc III 7, 8/336). El tercer aspecto se puede formular como "Amando, adorando". La razón canta con viva voz y despierta a las almas dormidas (Sc III 13, 13/506). El canto de la razón con viva voz compromete a todo el ser humano (conocer, adorar y amar). 
perderse entre tanto material. Han resultado de gran ayuda la recopilación de muchos artículos sobre Teresa, ofrecidos en bibliografías y elencos que dan una panorámica del momento actual y orientan en la profundización de la obra de esta autora. Alguno de los más representativos es el estudio realizado por Manuel Diego Sánchez en la "Bibliografía del Centenario Teresiano". Este catálogo bibliográfico es paradigmático en cuanto a la bibliografía del centenario teresiano. Una bibliografía selecta y temática es la que ofrece Barrientos, A., en su "Introducción a la lectura de Santa Teresa" (31).

Se han tenido en cuenta algunos autores expertos (32) en Santa Teresa que han publicado en relación con su obra en conjunto, y también en determinadas áreas de la teología sistemática.

Se ofrece una relectura, rescatando el gran valor teológico de esta autora, en los tres volúmenes de Tomás Álvarez, titulados "Estudios teresianos". En el primer volumen aborda la "Biografía e Historia teresiana"; los "Estudios textuales (1996)" en el segundo volumen; y el volumen III recopila los "Estudios doctrinales (1996)", ofreciendo al final, en el capítulo V, unas valiosas "Glosas bibliográficas" (609-684).

La obra de Secundino Castro, "Ser cristiano según Santa Teresa. Teología y espiritualidad", pretende una sistematización del pensar de Teresa para que pueda ser recepcionada en el momento actual. Su artículo "El proyecto cristiano de Santa Teresa leído hoy" destaca el significado experiencial de la palabra "camino"; además, conocer los misterios es la base para tallar en la mente y en el corazón la persona de Jesucristo. Estimula la reflexión y el valor del discurso destacando la importancia de la razón para que acontezca el amor (470). Propone un giro hermenéutico para descubrir lo oculto en el mensaje de Teresa (483).

Jesús Castellano ofrece la experiencia de creyentes que han experimentado "un conocimiento superior del misterio de Dios, mediante el Espíritu; /.../ su conocimiento de Dios es también experiencia de amor, conocimiento connatural mediante la comunión en la fe y en la caridad, porque Dios se comunica a la mente y al corazón" (37). Aparecen citadas y comentadas, entre otras mujeres, Teresa de Jesús e Hildegarda de Bingen, en "Conocimiento y experiencia de Dios Amor en los místicos cristianos".

(31) Cf. Álvarez, T., "Galería bibliográfica del IV Centenario": Monte Carmelo, 90 (1982) 357-370; Barrientos, A., "Introducción a la lectura de Santa Teresa". Editorial de Espiritualidad, Madrid (1978) 13-23; Diego Sánchez, M., "Bibliografía del Centenario Teresiano": Teresianum, Romae, 34 (1983/II) 355-451; Díez González, M.A., y Vega Santoveña, F., "Centenario. Índices de la Revista Monte Carmelo, años 1900-2000": Monte Carmelo, 108 (2000), No 1, 2, 3; Domingo, F., "Presencia de los estudios teresianos. Panorama internacional": Monte Carmelo 89 (1981) 378408. Efrén de la Madre de Dios, y Otger Steggink, "Santa Teresa de Jesús. Obras completas". BAC, $8^{a}$ edición, Madrid (1986) 35-54.

(32) Cf. Álvarez, T., "Estudios teresianos". 3 volúmenes. Editorial Monte Carmelo, Burgos 19951996. Castro, S., "Ser cristiano según Santa Teresa. Teología y espiritualidad". Editorial de Espiritualidad, $2^{a}$ edición, Madrid 1985; "El proyecto cristiano de Santa Teresa leído hoy": Revista de Espiritualidad 45 (1986) 461-487. Castellano, J., "Conocimiento y experiencia de Dios Amor en los místicos cristianos". En "Dios Amor en la tradición cristiana y en los interrogantes del hombre contemporáneo". Editorial Ciudad Nueva, Madrid (1993) 136-183.

Finalmente de Salvador Ros García, "Los estudios teresianos: panorama de actualidad y perspectivas de tratamiento": Teresianum 38/2 (1987) 149-209, del cual me siento deudora porque me sirvió para fundamentar el proyecto Dipuc, que ha posibilitado el presente trabajo. 
Es abundante y de distinta calidad la bibliografía en relación con las diversas áreas del saber humano. Se puede decir que Teresa está en el mundo de la interdisciplinariedad: la literatura, la filología, la psicología, la filosofía, la historia, la economía, la medicina, el género, etc. (33).

La obra Camino ha sido estudiada en profundidad en el último tiempo, publicando ediciones críticas con valiosas introducciones, notas y comentarios que han sido de gran ayuda (34). Daniel de Pablo Maroto, presenta el texto de Camino de Perfección (35) en los dos autógrafos, tomando como base el autógrafo de Valladolid más acabado y que Teresa consideró definitivo, asume las correcciones que la autora incorporó en la copia de Toledo antes de enviar el texto a la imprenta. En la introducción aporta unas claves hermenéuticas para entender este complejo libro: desde la gestación y confrontación de ambas redacciones; pasando por la identidad de "Camino", como texto para las comunidades cristianas; texto de historia; y manual de oración. Este autor, en su artículo "Camino de Perfección" (36) afirma: "es uno de los libros de la madre Teresa que menos ha envejecido con el paso del tiempo" (310). El libro "Santa Teresa. Comentario al Padre Nuestro" (37) presenta únicamente la segunda parte de Camino y la relaciona con los Comentarios al Padrenuestro de Orígenes, Tertuliano y San Cipriano, en el siglo III y posteriormente en el siglo XVI. Teresa defiende que el Padrenuestro no se puede arrebatar, ni prohibir,

(33) A modo de sencilla muestra se mencionan algunos autores que estudian a Teresa desde las distintas disciplinas. García de la Concha, V., "Sermo humilis", coloquialismo y rusticidad en el lenguaje literario teresiano": Monte Carmelo 92/2 (1984) 251-286; Marcos, J. A., "Trastornar la retórica. Sobre tópica y retórica teresianas": Revista de Espiritualidad 56 (1977) 143-160; "Dios y las metáforas financieras en Santa Teresa. La mística como negocio": Monte Carmelo 107 (1999) 487-508; Martín Gaite, C., "Desde la ventana". Editorial Espasa-Calpe, $3^{a}$ edición, Madrid (1999), 55-75; Menéndez Pidal, R., "Estudios sobre Santa Teresa". Edición de José Polo, en Analecta Malacitana (AnMal), Universidad de Málaga, 1998, Anejo 19, (44-73); Sánchez Castañer, F., "Santa Teresa de Jesús: su estilo en la vida y en las obras": Dicenda. Editorial Universidad Complutense, Madrid 1987. Cuadernos de Filosofía hispánica, n 7, 153-160; Vega GarcíaLuengos, G., "La dimensión literaria de Santa Teresa": Revista de Espiritualidad, 41 (1982) 29-62; Watt, N., “¿Vulgarización intencionada en Santa Teresa? Estudio comparativo de las dos redacciones de Camino de Perfección": Monte Carmelo 92 (1984) 319-346.

(34) Por citar algunas utilizadas: Efrén de la Madre de Dios, y Otger Steggink, "Santa Teresa de Jesús Obras completas". BAC, 8 a edición, Madrid (1986) 233-234; Tomás de la Cruz, "Teresa de Jesús, doctora de la Iglesia. Obras completas". Editorial Monte Carmelo, $5^{a}$ edición, Burgos (1987) 502514; Barrientos, A., (Dir. de la ed.), "Santa Teresa de Jesús Obras completas". Editorial de Espiritualidad, $2^{a}$ edición, Madrid (1976) 639-641.

(35) “Santa Teresa de Jesús. Camino de Perfección". Editorial de Espiritualidad. $4^{a}$ edición, Madrid 1983.

(36) "Camino de Perfección". En "Introducción a la lectura de Santa Teresa". Editorial de Espiritualidad, Madrid (1978) 269-310. Concluye con la significación que puede tener para hoy esta obra: la oración es siempre un servicio a la Iglesia; también hoy sigue habiendo sospechas contra la oración; la necesidad de la interiorización para encontrase con Cristo; diversas acotaciones respecto al vivir cotidiano que Teresa va dando a lo largo de la obra; sus ideas respecto a la afectividad que tocan las raíces psicológicas del ser humano; la honra, la limpieza de sangre, típico en el siglo XVI, pueden evocar referencias universales y permanentes como el prestigio, el rango social (fama, dinero, etc.).

(37) "Camino de Perfección". Editorial de Espiritualidad, Madrid 1982. En el siglo XVI también se hace este tipo de tratados, como por ejemplo el de Luis Vives, el Beato Orozco, Diego de Deza y además otros autores que incluyen estos comentarios dentro de sus obras como Francisco de Osuna en el Tercer Abecedario, que Teresa había leído, Bartolomé Carranza, etc. 
y conduce al encuentro con Dios dentro de cada persona, puede llegar a ser un apasionado diálogo entre el corazón y la cabeza, desde la razón y el amor.

Un gran aporte ofrece Tomás de la Cruz en "Santa Teresa de Jesús. Camino de Perfección" (38). La introducción situada en el volumen I (9-168) estudia el mandato de escribir, la fecha de la primera composición, los antecedentes literarios de la obra, el tema polémico de la oración mental, la censura, la segunda redacción de Camino, su fecha de redacción, las nuevas censuras y retractaciones, para llegar al segundo autógrafo el manuscrito de Valladolid. El autor concluye esta amplísima y erudita introducción refiriéndose a la presente edición. Otras obras del mismo autor han ayudado a comprender mejor la obra estudiada, así "El segundo autógrafo del "Camino de Perfección'. Avatares de su elaboración" (39) da cuenta del proceso de la autora de repensar ciertos temas, y del diálogo que mantiene con los teólogos que revisan su escrito; aunque se centra en su aspecto técnico material y pospone las implicaciones doctrinales, afirma que todas las reelaboraciones, eliminaciones o redacciones por tercera vez tienen su importancia doctrinal (150). El libro "Paso a paso. Leyendo con Teresa su Camino de perfección" (40) interesa, para la temática de la investigación, su apartado "amor y letras".

La obra de Maximiliano Herráiz (41), "Introducción al Camino de Perfección", es "una obra perfectamente ensamblada, con un contenido bien preciso, y un desarrollo cuidadosamente realizado" (21) a pesar de los lamentos de la autora que afirma empezar a escribir sin plan preconcebido (pról., 2) y con muchas interrupciones (CE 19, 1; 22, 1). Adentrándose en la obra, señala la finalidad: "compenetrarse intelectual y volitivamente con el objetivo de la propia vocación" (63) para que "a vueltas con amor apasionado" a Cristo le contentemos (66). Un rasgo fundamental de la antropología teresiana es que Dios seduce amorosamente, "precede dándosenos a fin de provocar en nosotros la actitud receptiva-responsiva conveniente" (93). Se revela Dios y el hombre: el Maestro enseña, habla, revela, desvela su ser; y el hombre aprende y entiende (112). Insiste en que la oración es desvelamiento de la Persona, Jesús se manifiesta y se da a conocer (122). En el último capítulo trata la naturaleza, exigencias y efectos de la oración de quietud. La comunicación de Dios se experimenta y desborda $(31,2-3)$ como paz, deleite, sosiego, un estar cerca, un entenderse por señas; es suficiente mantener el fuego del amor, de la atención amorosa de la voluntad, (CV 31, 7) (129). Teresa ha sabido transmitir desde el Paternóster todo el camino de perfección "hasta engolfar Dios el alma y darla abundosamente a beber de la fuente de agua viva, que dije estaba al final del camino" (CV 42, 5) (140).

(38) Tomás de la Cruz, "Santa Teresa de Jesús. Camino de Perfección". Tipografía Políglota Vaticana, vol. 2, Roma 1965.

(39) Monte Carmelo. 98 (1990) 129-165, artículo que escribe 25 años después de preparar la edición facsimilar antes comentada. Las últimas páginas son un "A modo de apéndice: el capítulo 16 y otros problemas" donde da cuenta del gran trabajo que fue para Teresa su obra Camino de Perfección, y en segundo lugar que esta obra es "un documento de calidad" que transmite su espiritualidad y a la vez da testimonio del contexto polémico en que fue escrito.

(40) "Paso a paso. Leyendo con Teresa su Camino de perfección". Editorial Monte Carmelo, Burgos (1995), 23-50.

(41) “Introducción al Camino de Perfección”. Editorial Monte Carmelo, Burgos 2001. 
La obra de Jesús Martí Ballester (42), "Camino de Santa Teresa leído hoy”, es presentada como una "lectio que ayuda a conocer amando aquello que se lee, /.../ es enseñanza de una actitud abierta a la lectura de lo visible para llegar al amor de lo que no se puede leer" (6). "El deseo de conocer y de amar a Dios está metido en lo más íntimo del corazón del hombre, /.../ Dios va mostrando caminos para que el hombre se encienda en el amor, /.../ el Espíritu Santo da /.../ los dones para que puedan conocer /.../ la hondura y profundidad de su amor y nos lo comuniquen /.../. Una de esas personas, /.../ Teresa alma encendida en el amor de Cristo, ardiendo en el deseo de comunicar ese amor. Fuego tan grande de caridad, no le conducía a evadirse de la realidad de este mundo, que es jornada y camino de perfección" (5). Ella transmitía en sus escritos el incendio de amor que vivía "páginas que son arroyos que llevan a la fuente del agua viva, caminos hacia la posada definitiva del gozo con Dios”. El autor estructura su obra con una introducción y después antepone a cada capítulo de Camino una prospección actual de dicho capítulo.

Otro autor que aporta elementos para el presente estudio es Olegario González de Cardedal (43), en el artículo "Realidad y experiencia de Dios en Santa Teresa: Contenidos específicos de esa experiencia teologal". Especialmente algunas páginas $(835,858-859,867-868,875-881)$ destacan la necesidad de Teresa de responder personalmente a Dios desde el amor y el conocimiento, porque vive una fuerte conciencia de agraciada tanto originaria como permanentemente en su existencia. Es Dios quien le da la honra (CV 36, 5), y la libertad para la humildad y pobreza que no son humillación (CV 2,6), sino mayor capacidad para actuar con independencia $(\mathrm{CV} 19,4)$. Se resalta esta libertad desde su saber en lo profundo "visto por experiencia, que es otro negocio que solo pensarlo y creerlo" (CV 6, 3). Escribe sus confesiones motivada por la lectura de San Agustín (CV 28, 2). Transmite su experiencia teologal, por necesidad y obediencia gozosa y agradecida de corresponder al don recibido. Esto la hace superar los condicionamientos históricos y cumplir su misión histórica en la Iglesia, prohibida para las mujeres, salvando obstáculos y empeñada en conocer y sentir lo que Dios ofrece y que el ser humano no reconoce ni consiente. Así convierte la necesidad en virtud escribiendo y fundando; aunque está perseguida externamente y minada por dentro (CV 32, 4).

\section{PARTE PRINCIPAL}

Se estudia la obra "Camino de Perfección" desde una perspectiva antropológica y con una determinada clave de lectura, la relación amor y razón, y se descubren tres ejes fundamentales: el ser humano creado, en proceso y en esperanza en el mundo. Se va analizando cada uno de los mencionados apartados para detectar cómo Santa Teresa de Ávila, mujer del siglo XVI, resuelve la relación razón y amor como racionalidad apasionada en el Espíritu Santo.

(42) "Camino de Santa Teresa leído hoy". Editorial San Pablo, Madrid 1993.

(43) "Realidad y experiencia de Dios en Santa Teresa: Contenidos específicos de esa experiencia teologal”. Actas del Congreso Internacional Teresiano, Salamanca, 1983, vol II, 835-882. 


\section{El ser humano creado}

De la mano de Teresa se habla en este apartado de cuatro conceptos, a saber: el amor como experiencia de Dios en el mundo; la razón en cuanto participante de la actividad creativa y destructiva; el binomio amor-razón creaturales y el binomio razón-amor empecatados; y la actividad creadora del Espíritu de Dios.

\subsection{El amor como la experiencia de Dios en el mundo}

Para Teresa, Dios, que es amor, solo desea el bien del hombre; aunque este se muestre ingrato con Él. Se trata de un amor entrañable y ardiente que es capaz de crear, salvar y plenificar el mundo, pese a ser poco valorado por el ser humano (44). En efecto, según Teresa, el amor de Dios crea, genera lo que desea y solo busca el bien del hombre; si bien este no siempre acepta los dones de Dios, dejándose conducir a menudo solo por los propios logros (45). El amor de Dios es señor de "los elementos y del mundo"; es lo fundamental, lo esencial de todo lo creado. El amor se entiende, es posible conocer el amor de Dios. Se trata de un Amor ardiente como el fuego que nada lo puede destruir, porque es superior a todo. El verdadero amor no es detenido por nada, incluso puede abrasar toda tentación.

/.../ entenderéis cómo el verdadero amor de Dios -si está en su fuerza, ya libre de cosas de tierra del todo y que vuela sobre ellas- cómo es señor de todos los elementos y del mundo. Y como el agua procede de la tierra, no hayáis miedo que mate este fuego de amor de Dios (Cant 8, 7); no es de su jurisdicción. /.../ Otros fuegos hay de pequeño amor de Dios, que cualquiera suceso los matará; mas a este no, no. Aunque toda la mar de tentaciones venga, no le harán que deje de arder de manera que no se enseñoree de ellas (46).

La autora, a continuación aborda el amor humano y sus manifestaciones. El amor creado se presenta en dos tipos: el amor espiritual que no pierde su pureza, y el amor que siendo espiritual, tiene una mayor influencia de la condición sensual (47). La primera manera de amar le lleva a Teresa a hablar del amor a los confeso-

(44) CV 3, 8. ¡Oh Padre eterno!, mirad que no son de olvidar tantos azotes e injurias y tan gravísimos tormentos. Pues, Criador mío, ¿cómo pueden sufrir unas entrañas tan amorosas como las vuestras, que lo que se hizo con tan ardiente amor de vuestro Hijo y por más contentaros a Vos (que mandasteis nos amase), sea tenido en tan poco /.../.

(45) CV 16, 6. ¡Oh dichoso cuidado, hijas mías! ¡Oh bienaventurada dejación de cosas tan pocas y tan bajas que llega a tan gran estado! Mirad qué se os dará -estando en los brazos de Dios- que os culpe todo el mundo. Poderoso es para libraros de todo, que una vez que mandó hacer el mundo fue hecho, su querer es obrar. Pues no hayáis miedo, que si no es para más bien del que le ama, consienta hablar contra Vos, no quiere tan poco a quien le quiere. Pues ¿por qué, mis hermanas, no le mostraremos nosotras -en cuanto podemos- el amor? Mirad que es hermoso trueco dar nuestro amor por el suyo/.../.

(46) CV 19, 4.

(47) CV 4, 12. De dos maneras de amor es lo que trato: una es espiritual, porque ninguna cosa parece toca a la sensualidad ni la ternura de nuestra naturaleza, de manera que quite su puridad; otra es espiritual, y junto con ella nuestra sensualidad y flaqueza o buen amor, que parece lícito, como el de los deudos y amigos; de este ya queda algo dicho.

Este punto está muy corregido sobre el CE. De hecho el CE 7, 2 no pasa al CV. 
res. La segunda es al amor a sí mismo, una de cuyas manifestaciones es el amor al cuerpo (48). El amor asume la condición creatural y potencia la realidad personal. El amor que se vive en la comunidad fraterna conduce a: lo innecesario de la queja; la asunción de la propia debilidad corporal; al fortalecimiento de la propia persona; a la objetivización de la enfermedad; y al apiadamiento de los otros con veracidad (49).

En el tema del dolor el amor lleva a "saber" sufrir, y la razón aprende a asumir la condición creatural. El dolor es experiencia de todo hombre, especialmente de los pobres y de las mujeres casadas, e incluso es realidad de Dios por la manera en que Jesucristo llevó a cabo la salvación, y también lo ha de ser de la vida religiosa (50). Teresa equipara el amor y la naturaleza (el deseo) en el sentido de ser el soporte, lo fundamental, el sustrato, la base del ser humano (51).

Algunos textos que recogen la expresión "amor de Dios", reflejan algunas actitudes de la vida comunitaria cuando se coloca el amor de Dios en primer lugar. El amor no busca favores porque su mirada está puesta en lo duradero (52) y comprende que el esfuerzo humano, en el recogimiento, es una buena inversión. El amor es razonable: hace crecer la condición creatural (53); y descubre la limitación humana (54).

Teresa trata la diferencia entre el amor divino y humano. El amor de los contemplativos hace que se estime en poco la fama, la ganancia, lo material, porque su meta es servir. Esta es la experiencia de Dios en los santos (55) que vence la

(48) CV 10, 5. Ahora, pues, lo primero que hemos de procurar es quitar de nosotras el amor de este cuerpo, que somos algunas tan regaladas de nuestro natural, /.../.

(49) CV 11, 1. Cosa imperfecta me parece, hermanas mías, este quejarnos siempre con livianos males; si podéis sufrirlo, no lo hagáis. Cuando es grave el mal, él mismo se queja; es otro quejido y luego se parece. Mirad que sois pocas, y si una tiene esta costumbre, es para traer fatigadas a todas si os tenéis amor y hay caridad; sino que la que estuviere de mal que sea de veras, lo diga y tome lo necesario; que si perdéis el amor propio, sentiréis tanto cualquier regalo, que no hayáis miedo le toméis sin necesidad ni os quejéis sin causa. Cuando la hay, sería muy peor no decirlo que tomarle sin ella, y muy malo si no os apiadasen.

(50) CV 11,3. Acordaos qué de pobres enfermos habrá que no tengan a quién se quejar; pues pobres y regaladas no lleva camino. Acordaos también de muchas casadas -yo sé que las hay-y personas de suerte, que con graves males, por no dar enfado a sus maridos, no se osan quejar, y con graves trabajos. Pues, ¡Pecadora de mí!, sí, que no venimos aquí a ser más regaladas que ellas. ¡Oh, que estáis libres de grandes trabajos del mundo, sabed sufrir un poquito por amor de Dios sin que lo sepan todos! Pues es una mujer muy malcasada, y porque no [lo] sepa su marido [no] lo dice [ni] se queja, pasa mucha malaventura Y sin descansar con nadie, ¿y no pasaremos algo entre Dios y nosotras de los males que nos da por nuestros pecados? Cuanto más que es nonada lo que se aplaca el mal.

(51) CV 19, 10. Digo que quien llega a tener esta sed tan impetuosa, que se mire mucho, porque crea que tendrá esta tentación; y aunque no muera de sed, acabará la salud /.../ mas estemos con cuidado cuando vienen estos ímpetus tan grandes de crecimiento de este deseo para no añadir en él, sino con suavidad cortar el hilo con otra consideración; que nuestra naturaleza, a veces, podrá ser obre tanto como el amor; que hay personas que cualquier cosa, aunque sea mala, desean con gran vehemencia. /.../. Pues no lo es; que yo no digo se quite el deseo, sino que se ataje, y por ventura será con otro que se merezca tanto.

(52) CV 29, 1. "Huid, por amor de Dios, hijas, de dárseos nada de estos favores (de los prelados); /.../.

(53) CV 29, 8. Pues nada se aprende sin un poco de trabajo, por amor de Dios, hermanas, que deis por bien empleado el cuidado que en esto gastareis; /.../.

(54) CV 36, 6. ¡Oh, por amor de Dios, hermanas!, que llevamos perdido el camino, porque va errado desde el principio; /.../.

(55) CV 36, 10. /.../ Es el caso que debe ser a quien Dios hace merced de tener esta humildad y amor grande a Dios, que en cosa que sea servirle más /.../. 
tentación gracias al amor (56). El amor por lo creatural no merece tal nombre porque carece de fundamento frente al todo. Hay diferentes grados de amor: el de Dios en el hombre y el humano por "nonadas" (57). Amar lo creatural es provisorio, en cambio el amor a lo divino es definitivo. Al unir el amor y el conocimiento se descubre, en este capítulo, que el conocimiento en profundidad capacita al ser humano para el amor (58). El amor como filiación es un don al que se responde con la filial reverencia al Padre, el regalo obsequioso del propio ser a Dios, y esto es el temor de Dios (59).

\subsection{La razón participa en la relación creativa y destructiva}

En la obra de Teresa se descubre una determinada racionalidad que supera los argumentos y la lógica del mundo (60). La razón descubre diferentes lógicas y modos de pensar. Así, en el camino de la perfección se propone una racionalidad cuyas razones son diferentes a las terrenas, divergen de las que surgen de argumentaciones meramente humanas. La manera de pensar de la condición creatural puede abrirse a nuevas formas. La vida religiosa es exigente y lo pide todo; esa radicalidad no siempre es entendible, aunque la misma razón descubre que tampoco el mundo respeta su propia lógica. El hombre se siente desbordado y superado (61). Esto significa un cambio en la racionalidad: la razón se invierte y así en esta vida hay que

(56) CV 40, tít. Dice cómo procurando siempre andar en amor y temor de Dios iremos seguros entre tantas tentaciones.

(57) A lo largo del punto 40 aparecen 19 veces la palabra amor. En los diferentes sub-puntos trata los tres temas: protológico (40, tít; 40, 7 en dos ocasiones), histórico (40, 1 dos veces) y escatológico (40, 2 dos veces; 40, 3 cinco veces; 40, 4; 40, 5; 40, 7; 40, 8 cuatro veces).

(58) CV 40, 7. Así que, hermanas, cuando entre vosotras viereis hay alguna que el Señor las haga, alabad mucho al Señor por ello, y no por eso penséis está segura, antes la ayudad con más oración; porque nadie lo puede estar mientras vive y anda engolfado en los peligros de este mar tempestuoso

Así que no dejaréis de entender este amor adonde está, ni sé cómo se pueda encubrir. Pues si amamos acá a las criaturas, dicen ser imposible, y que mientras más hacen por encubrirlo, más se descubre, siendo cosa tan baja que no merece nombre de amor, porque se funda en nonada; ¿y habíase de poder encubrir un amor tan fuerte, tan justo, que siempre va creciendo, que no ve cosa para dejar de amar, fundado sobre tal cimiento como es ser pagado con otro amor, que ya no puede dudar de él por estar mostrado tan al descubierto, con tan grandes dolores y trabajos y derramamiento de sangre, hasta perder la vida, porque no nos quedase ninguna duda de este amor? ¡Oh, válgame Dios, qué cosa tan diferente debe ser el un amor del otro a quien lo ha probado!

(59) CV 41,1./../ el temor de Dios también anda muy al descubierto, como el amor; no va disimulado aun en lo exterior /.../.

(60) CV 13 tít. Prosigue en la mortificación, y cómo ha de huir de los puntos y razones del mundo para llegarse a la verdadera razón.

(61) CV 13,1. Muchas veces os lo digo, hermanas, y ahora lo quiero dejar escrito aquí, porque no se os olvide, que en esta casa $-\mathrm{y}$ aun toda persona que quisiere ser perfecta- huya mil leguas de "razón tuve", "hiciéronme sinrazón", "no tuvo razón quien esto hizo conmigo"; ¡de malas razones nos libre Dios!. /.../ La que no quisiere llevar cruz, sino la que le dieren muy puesta en razón, no sé yo para qué está en el monasterio, tórnese al mundo adonde aún no le guardarán esas razones. ¿Por ventura podéis pasar tanto que no debáis más? ¿Qué razón es esta? Por cierto, yo no la entiendo. 
recibir agravios para poder ser Esposa del Rey. La cruz es la gloria, la cruz es el camino de la auténtica autorrealización (62).

Teresa tiene una concepción antropológica unitaria e integral, en la cual la persona entera es la que se relaciona con Dios; de esa visión arranca la unión que ella establece entre oración vocal y mental (63). La razón conoce el ser de Dios, su bondad y su deseo de comunicación. Este Dios impulsa al ser humano a desear ávidamente los bienes superiores (64). La razón a través del discernimiento y la prudencia descubre los caminos para la correcta relación entre las personas: no juzgar y no hablar osadamente (65).

La razón participa en lo creatural, el pecado y la redención. La razón pide luz para las tinieblas y reconoce su condición frente a Dios misericordioso. Desde la experiencia de limitación y pecado, el conocimiento le sirve a Teresa para la lucha, la pelea, la crítica (66). Un elemento de esta condición de creaturalidad, reconocido por la razón, es su incapacidad para glorificar al Padre (67). La razón es capaz de detectar el pecado en la no aceptación de la condición creatural. Teresa ejemplifica

(62) CV 13, 2. Cuando nos hicieren alguna honra o regalo o buen tratamiento, saquemos esas razones, que cierto es contra razón nos le hagan en esta vida. Mas cuando agravios -que así los nombran sin hacernos agravio- yo no sé qué hay que hablar. O somos esposas de tan gran Rey, o no. Si lo somos, ¿qué mujer honrada hay que no participe de las deshonras que a su esposo hacen? Aunque no lo quiera por su voluntad, en fin, de honra o deshonra participan entrambos. Pues tener parte en su reino y gozarle, y de las deshonras y trabajos querer quedar sin ninguna parte, es disparate.

(63) CV 24, 6. /.../ Tenéis razón en decir que ya es oración mental; mas yo os digo cierto, que no sé cómo lo aparte, $\mathrm{Si}$ ha de ser bien rezado lo vocal y entendiendo con quién hablamos. Y aun es obligación que procuremos rezar con advertencia, y aun plega a Dios que con estos remedios vaya bien rezado el Paternóster y no acabemos en otra cosa impertinente. Yo lo he probado algunas veces, y el mejor remedio que hallo es procurar tener el pensamiento en quien enderezo las palabras. Por eso tened paciencia y procurad hacer costumbre de cosa tan necesaria.

(64) CV 40, 6. ¿Pensáis que le importa poco al demonio poner estos temores? No, sino mucho, porque hace dos daños: el uno, que atemoriza a los que le oyen, de llegarse a la oración, pensando han también de ser engañados; el otro, que se llegarían muchos más a Dios, viendo que es tan bueno como he dicho, que es posible comunicarse ahora tanto con los pecadores. Póneles codicia, y tienen razón; que yo conozco algunas personas que esto los animó y comenzaron oración, y en poco tiempo salieron verdaderos, haciéndolos el Señor grandes mercedes.

(65) CV 41, 6. Y viene otro daño de aquí, que es juzgar a otros; como no van por vuestro camino, sino con más santidad (por aprovechar el prójimo tratan con libertad y sin esos encogimientos), luego os parecerán imperfectos. Si tienen alegría santa, parecerá disolución, en especial en las que no tenemos letras, ni sabemos en lo que se puede tratar sin pecado. Es muy peligrosa cosa y un andar en tentación continuo y muy de mala digestión, porque es en perjuicio del prójimo; y pensar que si no van todos por el modo que vos, encogidamente, no van tan bien, es malísimo.

Y hay otro daño, que en algunas cosas que habéis de hablar -y es razón habléis- por miedo de no exceder en algo no osaréis sino por ventura decir bien de lo que sería muy bien abominaseis.

(66) CV 3, 9. ¡Ay dolor, Señor, y quién se ha atrevido a hacer esta petición en nombre de todas! ¡Qué mala tercera, hijas mías, para ser oídas y que echase por vosotras la petición! ¡Si ha de indignar más a este soberano Juez verme tan atrevida, y con razón y justicia! Mas mirad, Señor, que ya sois Dios de misericordia; habedla de esta pecadorcilla, gusanillo que así se os atreve. Mirad, Dios mío, mis deseos y las lágrimas con que esto os suplico y olvidad mis obras, por quien Vos sois, y habed lástima de tantas almas como se pierden, y favoreced vuestra Iglesia. No permitáis ya más daños en la Cristiandad, Señor; dad ya luz a estas tinieblas.

(67) CV 30, 4. /.../ Mas como vio su Majestad que no podíamos santificar ni alabar ni engrandecer ni glorificar este nombre santo del Padre Eterno conforme a lo poquito que podemos nosotros - de manera que se hiciese como es razón- si no nos proveía su Majestad con darnos acá su reino, y así lo puso el buen Jesús lo uno cabe lo otro. /.../. 
esto con realidades tomadas de la vida consagrada (68). El ser humano experimenta la limitación como contrario a su ser. La razón acude a formular esa realidad como negatividad y descontento porque aspira a la transcendencia. Los contemplativos, ya en este mundo y en esta realidad, son capaces de transcenderla y llegar a conocer que desde la limitación se disfruta la divinidad que hará plena a la persona (69).

\subsection{Amor-razón creaturales y razón-amor empecatados}

Ambos binomios dan luz respecto a la relación que se establece entre Dios y el hombre.

La razón como capacidad de discurrir del ser humano creado por Dios, es una realidad muy valorada para el camino de oración. A Dios hay que darle con decisión, ya que todo le pertenece. En toda relación con Dios siempre hay ganancia, porque Dios es exceso y sobreabundancia. Es poco amor no dar algo de uno, cuando todo es recibido; es poco amor querer recuperar lo entregado. Teresa desarrolla una complementariedad entre amor y razón: la razón ilumina al ser humano, y el amor entiende lo limitado del ser humano, su egoísmo y su querer retener. La primera opción es darse (amor) con determinación (razón), y esto implica la fidelidad a las decisiones tomadas; el no volver atrás y seguir con osadía en el camino emprendido; en definitiva la entrega incondicional (70).

Teresa afirma que la razón humana y el amor de Dios se encuentran. El ser humano tiene capacidades y limitaciones. Se hace un valioso rescate de la capacidad humana, negando la razón a quien no es capaz de profundizar. El ser humano es un proceso permanente hacia la sabiduría. El amor de Dios se empeña en que la criatura aproveche todos los dones recibidos, el amor es don de Dios para su perfección.

(68) CV 36, 4. Mas mirad, hermanas, que no nos tiene olvidadas el demonio; también inventa sus honras en los monasterios y pone sus leyes, que suben y bajan en dignidades como los del mundo. Los letrados deben de ir por sus letras -que esto no lo sé-, que el que ha llegado a leer teología no ha de bajar a leer filosofía, que es un punto de honra que está en que ha de subir y no bajar. Y aun si se lo mandase la obediencia, lo tendría por agravio, y habría quien tornase de él, que es afrenta, y luego el demonio descubre razones que aun en ley de Dios parece lleva razón.

Pues entre nosotras, la que ha sido priora ha de quedar inhabilitada para otro oficio más bajo; un mirar en la que es más antigua, que esto no se nos olvida, y aun a las veces parece merecemos en ello porque lo manda la Orden.

(69) CV 36, 9. Pues entended, hermanas, que como estos tienen ya entendido lo que es todo, en cosa que pasa no se detienen mucho. Si de primer movimiento da pena una gran injuria y trabajo, aún no lo ha bien sentido cuando acude la razón por otra parte, que parece levanta la bandera por sí, y deja casi aniquilada aquella pena con el gozo que le da ver que le ha puesto el Señor en las manos cosa que en un día podrá ganar más delante de su Majestad de mercedes y favores perpetuos, que pudiera ser ganara él en diez años por trabajos que quisiera tomar por sí. Esto es muy ordinario, a lo que yo entiendo, que he tratado muchos contemplativos y sé cierto que pasa así. Que como otros precian oro y joyas, precian ellos los trabajos y los desean, porque tienen entendido que estos les han de hacer ricos.

(70) CV 23, 1. Pues digo que va muy mucho en comenzar con gran determinación, /.../. La una es que no es razón que a quien tanto nos ha dado y continuo da, que una cosa que nos queremos determinar a darle, que es este cuidadito -no cierto sin interés, sino con tan grandes ganancias- no se lo dar con toda determinación, sino como quien presta una co[sa] para tornarla a tomar. /.../. ;Oh, que si son amigos, y a quien la prestó debe muchas dadas sin ningún interés! Con razón le parecerá poquedad y muy poco amor, que aun una cosita suya no quiere dejar en su poder, siquiera por señal de amor. 
Dios enseña y recuerda lo enseñado: el Hijo es el maestro que enseña y el Padre es quien desea ser conocido. La relación entre el hombre y Dios es de agradecimiento y de amistad, por eso Dios quiere que el ser humano se acuerde de El (71).

Para acceder al Misterio de Dios hay que asumir el entender del ser humano. Se detecta una reversibilidad entre conocimiento y amor: una defensa apasionada de la razón para la oración, entendida como relación amistosa con Dios. Se persigue un desarrollo de la razón, se trata de revitalizar y potenciar este don de Dios. La razón entiende el Credo y el amor conoce al Padre y al Hijo, aboga por un saber de Dios. La razón y el amor tienen una función pedagógica; son camino para la sabiduría. La razón comprende lo que se cree, y el amor conoce a quien se cree. Se puede hablar de "razón amorosa". En este capítulo veinticuatro de "Camino de Perfección" aborda la espiritualidad y presenta la polémica entre la oración vocal y la oración mental. De fondo se encuentra el conflictivo tema de los estamentos y las funciones en la Iglesia; rompe con la posición que defiende solo la oración vocal. Para ella es inadmisible esa división.

/.../ Lo que yo querría hiciésemos nosotras, hijas, es que no nos contentemos con solo eso; porque cuando digo Credo, razón me parece será que entienda y sepa lo que creo; y cuando Padrenuestro, amor será entender quién es este Padre nuestro y quién es el maestro que nos enseñó esta oración (72).

Profundizando en la reversibilidad entre amor y razón, Teresa presenta el amor de Dios al ser humano de tal manera que la razón se encamina al amor, y este va precisando, afinando, la razón. No se puede dejar de entender si se quiere crecer en el amor. El ser humano es una unidad y necesita entender para unificar el corazón; aspira al conocimiento de Dios. No puede haber verdadera relación interpersonal si no hay conocimiento. La pedagogía divina consiste en hacer entrega de los dones, para que el ser humano conozca. Jesús pedagogo enseña quién es Dios: su Padre. El elemento distintivo de Jesús es su filiación divina. La razón es capaz de comprender al Dios de Jesús como Padre amoroso. El amor al ser entendido plenifica al ser humano. Se potencia la naturaleza con elementos de sobreabundancia. La razón se niega a no entender porque el amor sin razón, sin conocimiento, limita al ser humano.

(71) CV 24, 3. Si queréis decir que ya os lo sabéis y que no hay para qué se os acuerde, no tenéis razón, que mucho va de maestro a maestro, /.../. Pues de tal maestro como quien nos enseñó esta oración, y con tanto amor y deseo que nos aprovechase, nunca Dios quiera que no nos acordemos de El muchas veces cuando decimos la oración, aunque por ser flacos no sean todas.

(72) CV 24, 2. Y porque si alguna viene a esta casa, que también -como he dicho- no van todos por un camino, pues lo que quiero ahora aconsejaros, y aun puedo decir, enseñaros (porque, como madre, con el oficio de priora que tengo, es lícito) [es]: cómo habéis de rezar vocalmente, porque es razón entendáis lo que decís.

Y porque quien no puede pensar en Dios, puede ser que oraciones largas también le cansen, tampoco me quiero entremeter en ellas, sino en las que forzado hemos de rezar, pues somos cristianos, que es el Paternóster y Avemaría; porque no puedan decir por nosotras que hablamos y no nos entendemos, salvo si no nos parece basta irnos por la costumbre: "con solo pronunciar las palabras, que esto basta". Si basta o no, en eso no me entremeto, los letrados lo dirán. Lo que yo querría hiciésemos nosotras, hijas, es que no nos contentemos con solo eso; porque cuando digo Credo, razón me parece será que entienda y sepa lo que creo; y cuando Padrenuestro, amor será entender quién es este Padre nuestro y quién es el maestro que nos enseñó esta oración. 
Pues ¿paréceos ahora que será razón que, aunque digamos vocalmente esta palabra, dejemos de entender con el entendimiento, para que se haga pedazos nuestro corazón con ver tal amor? (73).

\subsection{La actividad creadora del espíritu de Dios (CV 19, 11)}

Este primer acápite finaliza, de modo concentrado, en la acción del espíritu de Dios en la historia. Este movimiento es de una manera creativa, sosteniendo la obra de la creación, e impulsándola hacia el futuro. La actividad creadora del espíritu de Dios se presenta en perspectiva escatológica. Es un actuar que capacita a la razón para darse a entender, y al amor para dejarse habitar.

El espíritu de Dios provoca en el ser humano el deseo de la visión. Este deseo ha de ser encauzado y no pretendido desmedidamente. El espíritu de Dios conduce a la liberación de la historia, y a la salvación personal, teniendo en cuenta que desde la experiencia de Teresa esta vida se presenta como cárcel. El espíritu de Dios provoca una "pena gustosa" que casi quita el juicio. A la vez da una gran lucidez para descubrir el mediocre amor que el ser humano es capaz de vivir. Desde la humildad se reconoce que puede ser el espíritu de Dios quien genere ese gran deseo de verse con Dios.

La persona es limitada, y ser consciente de su finitud la engrandece. Dios pone trabajos, aprietos a quien puede con ellos. El temor nace de la conciencia de la propia finitud y del reconocimiento de la condición filial. Esta sabiduría se relaciona con el temor de Dios, que es un don del Espíritu Santo. Algunos textos bíblicos así lo señalan: Prov 15, 3, el temor instruye en el saber; Eclo 19, 18, toda sabiduría es temor de Dios; Sal 111, 10, principio del saber es el temor de Dios; etc. En esta vida, la propia fragilidad no puede soportar el "verse ya con Dios"; entonces nace ese temor de Dios, que es amoroso. El temor de Dios recuerda que a Dios le debemos respeto (Ex 3, 5-6); es Padre y Misterio que admirar y adorar. Por lo tanto al hablar de Dios hay que hacerlo con sobriedad. El espíritu de Dios puede habitar en el corazón del ser humano, cuando está vacío de todo, y solo lleno de amor.

En síntesis, el amor posibilita que el espíritu de Dios habite en el ser humano, y este desee la visión, cara a cara, con Dios. La razón ha de ser prudente, humilde, para reconocer que no ama tanto como para que el Espíritu inhabite en la persona. El espíritu de Dios ilumina a la razón, que descubre que no ama mucho.

Quiero decir algo para darme mejor a entender. Da un gran deseo de verse ya con Dios y desatado de esta cárcel, como le tenía San Pablo; pena por tal causa y que debe en sí ser muy gustosa; no será menester poca mortificación para

(73) CV 27, 5. Pues ¿paréceos, hijas, que es buen maestro este, pues para aficionarnos a que aprendamos lo que nos enseña, comienza haciéndonos tan gran merced? Pues ¿paréceos ahora que será razón que, aunque digamos vocalmente esta palabra, dejemos de entender con el entendimiento, para que se haga pedazos nuestro corazón con ver tal amor? Pues ¿qué hijo hay en el mundo que no procure saber quién es su padre, cuando le tiene bueno y de tanta majestad y señorío? Aun si no lo fuera, no me espantara no nos quisiéramos conocer por sus hijos, porque anda el mundo tal, que si el padre es más bajo del estado en que está el hijo, no se tiene por honrado en conocerle por padre. 
atajarla, y del todo no podrá. Mas cuando viere aprieta tanto que casi va a quitar el juicio (como yo vi a una persona no ha mucho y de natural impetuosa, aunque demostrada a quebrar su voluntad -me parece lo ha ya perdido, porque se ve en otras cosas- digo que por un rato, que la vi como desatinada de la gran pena y fuerza que se hizo en disimularla), digo que en caso tan excesivo, aunque fuese espíritu de Dios, tengo por humildad temer, porque no hemos de pensar tenemos tanta caridad que nos pone en tan gran aprieto (74).

\section{El ser humano en proceso}

Siguiendo el hilo conductor de Teresa, se tratan en este segundo capítulo los siguientes temas: la razón en cuanto capacidad humana que entiende la salvación; el amor como experiencia de dolor y sufrimiento que actualiza en el cuerpo, la Iglesia, la salvación que ya ha sido inaugurada por la cabeza, Jesucristo; el binomio razón y amor que van liberándose en un determinado proceso; y finalmente el ser humano bajo la gracia por la acción del Espíritu Santo.

\subsection{La razón entiende la salvación}

Teresa refleja la situación paradójica en que se encuentra la razón del ser humano.

Una primera paradoja es la opción por la pobreza y la atención a las justas necesidades humanas. La razón crea sus propios argumentos para contrarrestar las opciones de los religiosos (75). Sin embargo, puede discernir lo que es acorde a la vocación recibida desde determinadas apuestas (76). La razón asume la vida religiosa como tarea costosa; se trata de "negarse" para poder seguir creciendo en lo fundamental. El llamamiento divino da la gracia para acometer esta tarea (77). La razón descubre escandalizada la sinrazón del sufrimiento de Jesús (78); a la vez, el sufrimiento es el camino que ha de seguir para ser la esposa de Jesús. El matrimonio se entiende como una unidad de ser constituida por ambos sujetos; es una comunidad de amor en la que todo se comparte (79).

(74) CV 19, 11.

(75) CV 9, 2. Espantada estoy el daño que hace tratarlos; no creo lo creerá sino quien lo tuviere por experiencia. ¡Y qué olvidada parece está el día de hoy en las religiones esta perfección! No sé yo qué es lo que dejamos del mundo las que decimos que todo lo dejamos por Dios, si no nos apartamos de lo principal, que son los parientes. Viene ya la cosa a estado, que tienen por falta de virtud no querer y tratar mucho los religiosos a sus deudos, y como que lo dicen ellos y alegan sus razones.

(76) CV 9, 3. En esta casa, hijas, mucho cuidado de encomendarlos a Dios, que es razón; en lo demás, apartarlos de la memoria lo más que podamos, /.../, y tengo por experiencia, en mí y en otras que dejados padres (que por maravilla dejan de hacer por sus hijos, y es razón con ellos cuando tuvieren necesidad de consuelo, si viéremos no nos hace daño a lo principal, no seamos extraños, que con desasimiento se puede hacer, y con hermanos), en lo demás, aunque me he visto en trabajos, mis deudos han sido y quien menos han ayudado en ellos; los siervos de Dios, sí.

(77) $\mathrm{CV} 12,1$.

(78) CV 13,1. /... ¿Parece que había razón para que nuestro buen Jesús sufriese tantas injurias y se las hiciesen, y tantas sinrazones? La que no quisiere llevar cruz, sino la que le dieren muy puesta en razón, no sé yo para qué está en el monasterio, /.../.

(79) CV 13, 2. /.../ Pues tener parte en su reino y gozarle, y de las deshonras y trabajos querer quedar sin ninguna parte, es disparate. 
La razón atisba a ver el valor de la intencionalidad. Teresa, que se encuentra ante la paradoja de querer decir para ayudar, y no saber decirlo bien (80). Paradójicamente, la razón entiende que no necesita razones, cuando vive desde las palabras salidas de la misma Verdad. La razón, que ansía la verdad, reconoce en la lógica de Dios el sentido de su existencia; porque experimenta una sed que al saciarse aumenta el deseo de beber.

/.../ Mas ¡con qué sed se desea tener esta sed! Porque entiende el alma su gran valor, y [aunque] es sed penosísima que fatiga, trae consigo la misma satisfacción con que se mata aquella sed. De manera que es una sed que no ahoga /.../, antes da hartura; /.../, y mayor queda siempre de tornar a beber esta agua (81).

Asimismo, resulta paradójica la invitación universal y el inmerecimiento personal: la voluntad salvífica universal de Dios se muestra en que todos están invitados a beber de la fuente de vida. La conciencia de pecado abre al conocimiento de la universalidad de la salvación, y a la libertad inalienable del sujeto (82).

La salvación es entendida por la razón en el ámbito de la oración, donde crece la relación de amistad con Dios. Para esta profundización, puede ser suficiente aquello que contiene las verdades fundamentales: la oración del Padre Nuestro y el Ave María (83). Para dialogar con Dios la razón es necesaria; ya que en este encuentro participa todo el ser humano, quien es el necesitado de la salvación (84). La razón confirma los valores cristianos de la humildad, el abajamiento, la incondicionalidad, y la preferencia por los sencillos. Es un Señor que busca y posibilita el encuentro (85). A través del diálogo amistoso la razón reconoce que la persona es un

(80) CV 16, 2. /.../ Quiérolo declarar, porque si en alguna cosa que no sea verdad me tomáis, no creeréis cosa; y tendríais razón si fuese con advertencia, mas no me dé Dios tal lugar; será no saber más o no lo entender. /.../. En las concordancias está mal la cita que da (CV 16,6), pues se trata de este punto CV 16, 2.

(81) CV 19,2. Hay unas almas y entendimientos tan desbaratados como unos caballos desbocados, que no hay quien los haga parar; ya van aquí, ya van allí, siempre con desasosiego; es su misma naturaleza, /.../Y ¡ icon cuánta razón y verdad, como dicho de la boca de la misma Verdad, que no la tendrá de cosa de esta vida, aunque crece muy mayor de lo que acá podemos imaginar de las cosas de la otra por esta sed natural!. Mas ¡con qué sed se desea tener esta sed!/.../.

(82) CV 20,1./../. Mas no dijo: "por este camino vengan unos y por este otros"; antes fue tan grande su misericordia, que a nadie quitó procurase venir a esta fuente de vida a beber. ¡Bendito sea por siempre, y con cuánta razón me lo quitara a mí!

(83) CV 21, 2. /.../ con decirnos: "hay peligros", "fulana por aquí se perdió", "el otro se engañó", "el otro, que rezaba mucho, cayó", "hacen daño a la virtud", "no es para mujeres, que les podrán venir ilusiones", "mejor será que hilen", "no han menester esas delicadezas", "basta el Paternóster y Avemaría".

CV 21, 3. Esto así lo digo yo, hermanas: y ¡cómo si basta! Siempre es gran bien fundar vuestra oración sobre oraciones dichas de tal boca como la del Señor. En esto tienen razón, /.../.

(84) CV 22, tít. En que declara qué es oración mental. CV 22, 1. Sabed, hijas, que no está la falta para ser o no ser oración mental en tener cerrada la boca; si hablando estoy enteramente entendiendo y viendo que hablo con Dios con más advertencia que en las palabras que digo, junto está oración mental y vocal. Salvo si no os dicen que estéis hablando con Dios rezando el Paternóster y pensando en el mundo; aquí callo. Mas si sabéis de estar, como es razón se esté, hablando con tan gran Señor, que es bien estéis mirando con quién habláis, y quién sois vos, siquiera para hablar con crianza. /.../.

(85) CV 22, 4. Razón es que, ya que por la humildad de este Rey, si como grosera no sé hablar con él, no por eso me deja de oír, ni me deja de llegar a sí, ni me echan fuera sus guardas; porque saben 
"regalo", esto implica que debe corresponder con la entrega gratuita de sí misma. Jesús anuncia un nuevo modo de relación, en el cual la fraternidad con Él manifiesta la filiación con el Padre, y ambas experiencias generan el agradecimiento en el ser humano (86).

La razón detecta y tiene en cuenta los obstáculos y los estímulos para la salvación. La incapacidad de ser fiel a la palabra dada, es una burla frente a la entrega absoluta de Jesús. El signo de poner el anillo en la mano remite a la alianza esponsal como compromiso irrevocable (87).

La vocación de seguimiento implica cumplir la voluntad de Dios; también, con las consecuencias menos apetecibles: la persecución, la enfermedad, la deshonra, etc. Ese compromiso se asume de frente y caminando. Para Teresa, Jesús ofrece, en nombre de todos, la voluntad de cada uno. La libertad personal sigue intacta, porque uno puede retractarse. Solo con su libertad, el hombre puede salvarse (88). La libertad se encuentra con la tendencia humana a promocionarse, a ascender, y la negación al abajamiento. Jesús se sitúa de modo inverso: se humilla; se anonada por la salvación de todos. La kenosis no es fácilmente entendible; la subida al cielo pasa por el descenso a los infiernos (89). La razón conoce bien las flaquezas y las necesidades humanas; y considera razonable pedir por lo que necesitamos. Pero se ha de tener en cuenta que, lo más necesario, no se puede conseguir por el propio esfuerzo; se ha de recibir de modo gratuito (90).

bien los ángeles que están allí la condición de su Rey, que gusta más de esta grosería de un pastorcito humilde, que ve que si más supiera más dijera, que de los muy sabios y letrados, por elegantes razonamientos que hagan, si no van con humildad. Así que, no porque El sea bueno, hemos de ser nosotros descomedidos. /.../.

(86) CV 32, 1. Ahora que nuestro buen Maestro nos ha pedido y enseñado a pedir cosa de tanto valor, que encierra en sí todas las cosas que acá podemos desear, y nos ha hecho tan gran merced como hacernos hermanos suyos, veamos qué quiere que demos a su Padre, y qué le ofrece por nosotros, y qué es lo que nos pide -que razón es le sirvamos con algo tan grandes mercedes-. /.../.

(87) CV 32, 8. No son estas burlas para con quien le hicieron tantas por nosotros; aunque no hubiera otra cosa, no es razón burlemos ya tantas veces, que no son pocas las que se lo decimos en el Paternóster. Démosle ya de una vez la joya del todo de cuantas acometemos a dársela; ¿es verdad que no nos da primero para que se la demos? Los del mundo harto harán si tienen de verdad determinación de cumplirlo. Vosotras, hijas, diciendo y haciendo, palabras y obras, como a la verdad parece hacemos los religiosos; sino que, a las veces, no solo acometemos a dar la joya, sino ponémosela en la mano y tornámosela a tomar. Somos francos de presto y después tan escasos, que valdría en parte más que nos hubiéramos detenido en el dar.

(88) CV 32, 10. Y en esto -como ya tengo escrito- ninguna cosa hacemos de nuestra parte, ni trabajamos, ni negociamos, ni es menester más - porque todo lo demás estorba e impide- de decir "fiat voluntas tua": cúmplase, Señor, en mí vuestra voluntad de todos los modos y maneras que Vos, Señor mío, quisiereis; si queréis con trabajos, dadme esfuerzo y vengan; si con persecuciones y enfermedades y deshonras y necesidades, aquí estoy, no volveré el rostro, Padre mío, ni es razón vuelva las espaldas. Pues vuestro Hijo dio en nombre de todos esta mi voluntad, no es razón falte por mi parte; sino que me hagáis Vos merced de darme vuestro reino para que yo lo pueda hacer, pues él me le pidió, y disponed en mí como en cosa vuestra conforme a vuestra voluntad.

(89) CV 36, 5. (mirar en la que es más antigua) Cosa es para reír, o para llorar, que lleva más razón. Sí, que no manda la Orden que no tengamos humildad; manda que haya concierto; /.../. Es el caso que, como somos inclinadas a subir -aunque no subiremos por aquí al cielo- no ha de haber bajar. ¡Oh, Señor, Señor!, ¿sois Vos nuestro dechado y Maestro? Sí, por cierto. Pues ¿en qué estuvo vuestra honra, Honrador nuestro? ¿No la perdisteis, por cierto, en ser humillado hasta la muerte? No, Señor, sino que la ganasteis para todos.

(90) CV 38, 2. Creed, hermanas, que los soldados de Cristo, que son los que tienen contemplación y tratan de oración, no ven la hora que pelear;/.../; nunca los vuelven el rostro. Los que temen, y es 
Para concluir este apartado, en el que se ha tratado cómo la razón está habilitada para detectar la salvación, se puede afirmar que la razón está impelida por lo escatológico. La razón descubre y entiende con claridad, que el mensaje y el desarrollo del proyecto de Jesús no son fáciles. Se resalta la condición humana de Jesús que, como toda criatura, llega al límite de sus fuerzas. Por otra parte, esa dimensión humana de la cristología de Teresa muestra la urgencia que vive Jesús por la construcción del Reino, y por llegar a él de modo definitivo. Está urgido (instado) por heredar, y está incitado por lo escatológico.

/.../ Y esto era lo menos; mas ;tantas ofensas como se hacían a su Padre, y tanta multitud de almas como se perdían! Pues si acá una que tenga caridad le es esto gran tormento, ¿qué sería en la caridad sin tasa ni medida de este Señor? Y ¡qué gran razón tenía de suplicar al Padre que le librase ya de tantos males y trabajos y le pusiese en descanso para siempre en su reino, pues era verdadero heredero de él (91).

\subsection{El amor actualiza la salvación}

El amor sufriente actualiza, en el cuerpo de la Iglesia, la salvación operada en Cristo cabeza. Para desarrollar esto se trata: el amor humano, el divino, y la relación entre ellos, que se resuelve en Cristo.

Teresa estudia el amor humano: un amor que la lleva a obedecer; a servir a otros; a fundamentar la vida espiritual, y predispone para el bien.

Teresa, obedeciendo a los confesores y a su comunidad, realiza su vocación de escritora. Sus lectores son el detonante de la obra de Teresa para conocer y darse a entender (92). La razón descubre la necesidad de saber, y el amor conduce a la tarea de enseñar lo conocido por la experiencia para servir (93).

El amor al prójimo es el fundamento de toda la vida espiritual (94), y es mandato del Señor, que potencia lo humano, siendo cauce de paz en la vida comunitaria (95). Es el mejor medio para atajar las particularidades, junto con la soledad y

razón teman y siempre pidan los libre el Señor de ellos, /.../. De estos pidamos, hijas, y supliquemos muchas veces en el Paternóster que nos libre el Señor y que no consienta andemos en tentación, que nos traigan engañadas, que se descubra la ponzoña, que no os escondan la luz y la verdad. ¡Oh, con cuánta razón nos enseña nuestro buen Maestro a pedir esto y lo pide por nosotros!

(91) CV 42, 1. Paréceme tiene razón el buen Jesús de pedir esto para Sí, porque ya vemos cuán cansado estaba de esta vida /.../.

(92) CV prol, 1. /.../ me he determinado a las obedecer, viendo que el amor grande que me tienen puede hacer más acepto lo imperfecto, /.../.

(93) CV prol, 3. Sé que no falta el amor y deseo en mí para ayudar en lo que yo pudiere para que las almas de mis hermanas vayan muy adelante en el servicio del Señor; y este amor, junto con los años y experiencia que tengo de algunos monasterios, podrá ser aproveche $/ . . . /$.

(94) CV 4, tít. /.../. Declara la primera de estas tres cosas, que es amor del prójimo, y lo que dañan amistades particulares.

(95) CV 4, 4. No penséis, amigas y hermanas mías, que serán muchas las cosas que os encargaré; /.../. Solas tres me extenderé en declarar, que son de la misma Constitución, porque importa mucho entendamos lo muy mucho que nos va en guardarlas para tener la paz que tanto nos encomendó el Señor, interior y exteriormente. La una es amor unas con otras; otra, desasimiento de todo lo criado; la otra, verdadera humildad, que aunque la digo a la postre, es la principal y las abraza todas. 
el estudio (96). La relación va creando vínculos y el mayor es el amor (97). El amor ayuda a saber sufrir la condición humana en las relaciones comunitarias; busca el bien del otro olvidándose de sí; es disponible en el servicio, para liberar a otros; y el amor busca la sinceridad en las relaciones fraternas (98). El amor predispone para el bien ya que la persona se siente estimulada en toda su realidad afectiva (99). Un caso patente se da en la relación entre maestro y discípulo, en la cual el conocimiento es vehículo de amor (100).

Cuando Teresa habla del amor de Dios, lo presenta como: ayuda para optar por la pobreza; camino que evita la acepción de personas; garante para la libertad de confesores; y desmesura frente al raquítico amor humano.

El amor de Dios es el fundamento para entender la relativización de lo mundano y abrazar la pobreza. Ayuda a discernir lo importante, y así ha de entenderse y practicarse (101). El amor de Dios manifestado en la Pascua de Jesús relativiza las realidades creaturales, y, entre otras cosas, hace innecesarios los edificios suntuosos (102). En la eclesiología de Teresa, la oración por los otros -incluso pide que recen por ella (103)-, y el amor mutuo son el fundamento de la vida comunitaria. El estudio y la formación conducen al amor de las virtudes. Recomienda la amistad con

(96) CV 4, 9. En atajar estas parcialidades es menester gran cuidado desde el principio que se comience la amistad; esto más con industria y amor que con rigor. /.../, con más facilidad se guarda el silencio cada una por sí, y acostumbrarse a soledad es gran cosa para la oración; y pues este ha de ser el cimiento de esta casa, es menester traer estudio en aficionarnos a lo que a esto más nos ayuda.

(97) CV 4, 10. Tornando al amarnos unas a otras, parece cosa impertinente encomendarlo; porque ¿qué gente hay tan bruta que tratándose siempre y estando en compañía, y no habiendo de tener otras conversaciones ni otros tratos ni recreaciones con personas de fuera de casa, y creyendo nos ama Dios y ellas a El -pues por su Majestad lo dejan todo- que no cobre amor? En especial, que la virtud siempre convida a ser amada; y esta, con el favor de Dios, espero en su Majestad siempre la habrá en las de esta casa. Así que en esto no hay que encomendar mucho, a mi parecer.

(98) Cf. CV 7, 7. CV 7, 8. CV 7, 9. CV 12, 9.

(99) Cf. CV 20,6

(100) CV 21, 4. /.../ está claro que el mismo maestro cuando enseña una cosa toma amor con el discípulo /.../.

(101) CV 2, 4. En ninguna manera se ocupe en esto el pensamiento, os pido, por amor de Dios, en limosna; y la más chiquita, cuando esto entendiese alguna vez en esta casa, clame a su Majestad y acuérdelo a la mayor; con humildad le diga que va errada; y valo tanto, que poco a poco se va perdiendo la verdadera pobreza. Yo espero en el Señor no será así ni dejará a sus siervas; y para esto, aunque no sea para más, aproveche esto que me habéis mandado escribir por despertador.

(102) Teresa tiene una abrupta expresión referida a quien amontone en esta vida: le caiga encima todo lo acumulado y le mate. En el códice del Escorial es tremendamente clara y contundente. CV 2, 8. Estas armas han de tener nuestras banderas, que de todas maneras lo queramos guardar: en casa, en vestidos, en palabras, y mucho más en el pensamiento. Y mientras esto hicieren, no hayan miedo caiga la religión de esta casa, con el favor de Dios; que -como decía Santa Clara- grandes muros son los de la pobreza. De estos -decía ella- y de humildad quería cercar sus monasterios; y a buen seguro, si se guarda de verdad, que esté la honestidad y todo lo demás fortalecido mucho mejor que con muy suntuosos edificios; de esto se guarden, por amor de Dios y por su sangre se lo pido yo; y si con conciencia puedo decir, que el día que tal hicieren se torne a caer. // CE 2, 8 . Estas armas han de tener nuestras banderas, /.../ y, si con conciencia puedo decir, que el día que tal quisiere se torne a caer, que las mate a todas, yendo con buena conciencia lo digo y lo suplicaré a Dios.

(103) CV 3, 10. Pidoos yo, hermanas mías, por amor del Señor, encomendéis a su Majestad esta pobrecilla /.../. 
todas porque es el amor más perfecto (104); lo que genera hablar y tratar bien (105). Una tarea importante de la priora es conseguir la libertad de confesores, tan fundamental para la Iglesia y la comunidad. Junto a esa capacidad de elección, Teresa apuesta por la sabiduría en los confesores; personas con letras, formadas, que encaucen e iluminen a la comunidad en la oración y en la acción.

Esta santa libertad pido yo, por amor del Señor, a la que estuviere por mayor procure siempre con el obispo o provincial que, sin los confesores ordinarios, procure algunas veces tratar ella y todas y comunicar sus almas con personas que tengan letras, en especial si los confesores no las tienen, por buenos que sean; son gran cosa letras para dar en todo luz. Será posible hallar lo uno y lo otro junto en algunas personas; y mientras más merced el Señor os hiciere en la oración, es menester más ir bien fundadas sus obras y oración (106). /.../ pido por amor del Señor al obispo que fuere, que deje a las hermanas esta libertad y que no se la quite /.../ (107).

Confronta la desmesura del amor de Dios, y la estrechez del amor humano. El amor de Dios se expresa, magníficamente, en la oración del Padrenuestro: el amor admirable, desmedido y digno de ser contemplado para ser conocido (108). La fragilidad del hombre y la pequeñez de su amor, frente al amor mayor de Dios, descubre la gran apuesta de Jesús por querer hacerse presente cada día. Gracias a la unidad, bondad y única voluntad del Padre y del Hijo se concede la petición del Hijo (109). El desbordamiento de amor intratrinitario hacia el ser humano le transforma para poder cumplir la voluntad amorosa del Padre, tal como acontece en el Hijo por la fuerza del Espíritu Santo (110). Teresa entiende el gran amor del Padre que se

(104) CV 4, 7. Y de estas amistades querría yo muchas donde hay gran convento, que en esta casa -que no son más de trece, ni lo han de ser- aquí todas han de ser amigas, todas se han de amar, todas se han de querer, todas se han de ayudar; y guárdense de estas particularidades, por amor del Señor, por santas que sean, /.../, que es natural y muchas veces nos lleva a amar lo más ruin si tiene más gracias de naturaleza- que nos va[ya]mos mucho a la mano a no nos dejar enseñorear de aquella afección. Amemos las virtudes y lo bueno interior, y siempre con estudio traigamos cuidado de apartarnos de hacer caso de esto exterior.

(105) CV 20, 3. /.../ y por amor de Dios os pido que vuestro trato sea siempre ordenado a algún bien de quien hablareis /.../.

(106) CV 5, 2

(107) CV 5, 5

(108) CV 27, tít. En que trata el gran amor que nos mostró el Señor en las primeras palabras del "Paternoster", /.../. CV 27, 4. /.../ ¡Qué confesión tan clara, Señor mío! ¡Qué cosa es el amor que nos tenéis! /.../.

(109) CV 33, 2. /.../ por ser nosotros tales y tan inclinados a cosas bajas y de tan poco amor y ánimo que era, menester ver el suyo para despertarnos, y no una vez sino cada día, que aquí se debía determinar de quedarse con nosotros. Y como era cosa tan grave y de tanta importancia, quiso que viniese de la mano del Eterno Padre. Porque aunque son una misma cosa y sabía que lo que El hiciese en la tierra lo haría Dios en el cielo y lo tendría por bueno -pues su voluntad y la de su Padre era una- era tanta la humildad del buen Jesús, que quiso como pedir licencia; porque ya sabía era amado del Padre y que se deleitaba en El. Bien entendió que pedía más en esto que ha pedido en lo demás /.../.

(110) CV 33, 3. /.../ ¡Oh, válgame Dios, qué gran amor del Hijo, y qué gran amor del Padre! Aun no me espanto tanto del buen Jesús, porque como había dicho "fiat voluntas tua", habíalo de cumplir como quien es. Sí, que no es como nosotros; pues como sabe la cumple con amarnos como a Sí, así andaba a buscar cómo cumplir con mayor cumplimiento -aunque fuese a su costa- este mandamiento. /.../. 
deja convencer por el amor del Hijo, para que siga entregándose por nosotros. La presencia permanente del Hijo, a través del Espíritu Santo, en la historia va gestando el Reino de Dios (111).

Teresa avanza en la relación entre el amor humano y el amor divino. Y presenta a Jesús como el paradigma de esta relación. Jesús enfrenta los grandes problemas contando con la fragilidad humana, y así el amor humano se puede ir configurando al amor de Cristo; Jesús propone una inversión de la lógica respecto al sufrimiento, la gratuidad, la libertad; Jesús concibe al hombre como misterio de amor y de conocimiento.

El amor se aprende del maestro, es un mandato para todos y una exigencia fundamental para sus apóstoles (112). El amor de Dios es como el fuego abrasador y purificador (113). El amor descubre la razonabilidad de la vocación (114); y hace sólido y consistente al ser humano (115). En definitiva, la Cabeza traspasa al Cuerpo todo su ser (116).

La oración transforma al hombre para amar al prójimo (117), de manera lenta, sencilla, y esforzada (118). La relación amistosa comprende que el Señor conceda más trabajos a quien más ama. El amor da la medida de poder soportar la cruz (119).

(111) CV 33, 4. ¡Oh Señor Eterno! ¿Cómo aceptáis tal petición? ¿Cómo lo consentís? No miréis su amor, que a trueque de hacer cumplidamente vuestra voluntad y de hacer por nosotros, se dejará cada día hacer pedazos. /.../. Pues, ¿no ha de haber quien hable por este amantísimo Cordero?. / .../. Pone también delante a su Padre; es como decirle que ya una vez nos le dio para que muriese por nosotros, que ya nuestro es, que no nos le torne a quitar hasta que se acabe el mundo, que le deje servir cada día. Esto os enternezca el corazón, hijas mías, para amar a vuestro Esposo; que no hay esclavo que de buena gana diga que lo es, y que el buen Jesús parece se honra de ello.

(112) CV 4, 11. En cómo ha de ser este amarse y qué cosa es amor virtuoso -el que yo deseo haya aquí- y en qué veremos tenemos esta virtud (que es bien grande, pues nuestro Señor tanto nos la encomendó y tan encargadamente a sus Apóstoles), de esto querría yo decir ahora /.../.

(113) CV 7, 11. Mire mucho la priora, por amor de Dios, en no dar lugar a esto (bandillos, etc.), atajando mucho los principios, que aquí está todo el daño o remedio; /.../ todas tan incurable pestilencia.

¡Oh, que es gran mal! ¡Dios nos libre de monasterio donde entra!; yo más querría entrase en este un fuego que nos abrasase a todas.

Porque en otra parte creo diré algo más de esto -como en cosa que nos va tanto- no me alargo más aquí.

(114) CV 8, 2. Cuanto a lo exterior, ya se ve cuán apartadas estamos aquí de todo. ¡Oh hermanas!, entended, por amor de Dios, la gran merced que el Señor ha hecho a las que trajo aquí, y cada una lo piense bien en sí /.../.

(115) $\mathrm{CV} 16,3 . / \ldots /$; $\mathrm{Oh}$, que todo lo que se pasa con amor torna a soldarse! Y así creo, si quedarais con la vida, el mismo amor que nos tenéis tornara a soldar vuestras llagas, que no fuera menester otra medicina. /.../.

(116) CV 16, 6. /.../ Pues ¿por qué, mis hermanas, no le mostraremos nosotras -en cuanto podemos- el amor? Mirad que es hermoso trueco dar nuestro amor por el suyo; mirad que lo puede todo y acá no podemos nada sino lo que Él nos hace poder. /.../.

(117) CV 20, 4. /... Ande la verdad en vuestros corazones como ha de andar por la meditación, y veréis claro el amor que somos obligadas a tener a los prójimos.

(118) CV 26, 10. /.../ para que torne a tomar amor a estar en su casa, es menester mucho artificio; y si no es así y poco a poco, nunca haremos nada. /.../ Mirad las palabras que dice aquella boca divina, que en la primera entenderéis luego el amor que os tiene, que no es pequeño bien y regalo del discípulo ver que su maestro le ama.

(119) CV 32, 7. /.../ y conforme al ánimo que ve en cada uno y el amor que tiene a su Majestad. A quien le amare mucho, verá que puede padecer mucho por El; al que amare poco, poco. Tengo yo para mí, que la medida del poder llevar gran cruz o pequeña, es la del amor. Así que, hermanas, si le tenéis, procurad no sean palabras de cumplimiento las que decís a tan gran Señor, sino esforzaos a pasar lo que su Majestad quisiere. 
Cuando el ser humano experimenta el amor divino, todo lo recibido se valora como don (120). Dios queda inaprensible, incluso para los contemplativos; su amor es gratuito y libre; no es seguro, y siempre hay que estar vigilantes, porque a Dios nadie le posee (121). Para no caer en tentación, se requiere el amor y el temor de Dios; vivir en la conciencia de ser hijos del Padre; asumir que el ser humano es un misterio de amor y conocimiento (122). El amor humano conformado al amor divino, es el camino que propone Teresa para vivir en la historia asumiendo la realidad dificultosa; aceptando la salvación, que Cristo ya ha iniciado y continua, a través del ser humano que vive como miembro del Cuerpo, ansiando lo definitivo.

\subsection{Razón y amor liberándose}

Teresa en su obra armoniza la razón, que descubre la salvación, con el amor, que potencia los valores humanos. De este modo, la salvación va aconteciendo procesualmente en el mundo y la historia.

La razón descubre los grandes valores que abren a la transcendencia e impulsan al ser humano hacia el amor. El amor es la capacidad de llegar a ser, en plenitud, de la razón. Teresa comprende la razón, don de Dios, como potencia para el bien, y rechaza toda estrategia que se oponga a amar más. La pobreza es un medio para el radical seguimiento del Señor; es una opción en libertad para amar más. El amor aporta horizontes a la razón; le hace comprender más allá de lo razonable; y así posibilita la fidelidad vocacional. El vivir como salvados se manifiesta en el mundo relativizando realidades importantes, y apostando por la libertad, la fidelidad y la pobreza. A mayor conocimiento mayor amor (123).

Cuando la razón detecta los valores, y el amor apuesta por ellos; entonces la persona puede hacer la entrega de la propia libertad. Teresa tiene experiencia de que el ser humano no puede por sí mismo liberarse, salvarse; porque la razón se opone a la "guerra contra nosotros mismos". Y también tiene experiencia del amor que rebasa las argumentaciones lógicas. Así, la persona, aunque parezca no razonable entregando la libertad, se abre a una mayor capacidad de amar. El hombre regala su mayor don, la libertad, a través de la obediencia. La razón y el amor se liberan en la mutua interrelación: ante la dificultad de la propuesta que la razón descubre, solo cabe el riesgo de la apuesta que el amor induce. La razón lleva al amor y el amor es

(120) CV 36, 12. /.../ tiene presente el regalo y merced que le ha hecho, adonde vio señales de grande amor, y alégrase se le ofrezca en qué le mostrar alguno.

(121) CV 39, 4. /.../ aunque más gustos y prendas de amor el Señor os dé, nunca tanto andéis seguras que dejéis de temer podéis tornar a caer, y guardaros de las ocasiones.

(122) CV 40, 1. Pues, buen Maestro nuestro, dadnos algún remedio cómo vivir sin mucho sobresalto en guerra tan peligrosa. El que podemos tener, hijas, y nos dio su Majestad, es amor y temor; que el amor nos hará apresurar los pasos; el temor nos hará ir mirando adónde ponemos los pies para no caer por camino adonde hay tanto en que tropezar, como caminamos todos los que vivimos; y con esto a buen seguro que no seamos engañadas.

(123) CV 2, 1. No penséis, hermanas mías, que por no andar a contentar a los del mundo os ha de faltar de comer. Yo os aseguro: jamás por artificios humanos pretendáis sustentaros, que moriréis de hambre, y con razón.”. /.../ Esto no se os olvide, por amor del Señor; pues dejáis la renta, dejad el cuidado de la comida; si no, todo va perdido. Los que quiere el Señor que la tengan, tengan enhorabuena esos cuidados, que es mucha razón pues es su llamamiento; mas nosotras, hermanas, es disparate. 
el culmen de la razón. El amor potencia lo humano conduciendo a la gratuidad (124).

La razón reconoce y el amor aviva, abre a mayor, el conocimiento. El amor de Dios en el ser humano lleva al conocimiento pleno. La razón descubre la función mediadora de Jesús en la salvación del hombre. Jesús entregando su vida por la salvación de todos restablece la relación entre el ser humano y el Padre. La razón deduce la necesidad de la fidelidad; corresponder a la acción del salvador. A la entrega desmedida de Jesús por el ser humano corresponde el cumplimiento de la voluntad del Padre. Este es el modo de apostar por la verdad. El amor de Dios se puede "decepcionar" del ser humano, pero, incluso así, Dios sigue dando la gracia para que el hombre pueda manifestarle a Él. Este don es sobreabundante: Dios al regalar su amor, capacita al hombre para recibirlo; Dios entrega el amor para que el hombre pueda pedir, sufrir, y vencer el miedo. No hay razón para no asumir el proyecto de Dios que Jesús ha instaurado en el mundo, porque el amor de Dios en el hombre puede incluso hacerle fiel (125).

A modo de síntesis, finalmente, Teresa establece una relación entre amor y razón, en la que el sujeto experimenta la presencia de Dios, y se va configurando como hijo y hermano. La opción de pobreza, la entrega de la libertad y la fidelidad a la voluntad de Dios, acontecen en el cristiano que vive la reversibilidad de la relación entre el amor y la razón.

El amor del ser humano atrae el amor de Dios. La razón descubre la auténtica relación con Dios: se autocomunica en totalidad, y no es posible limitarlo a lo que la Iglesia propone en determinados momentos históricos. "Rezar como es razón" conduce a experimentar la presencia de Dios. El creyente que ora tiene experiencia de la presencia y de la cercanía de Jesús: como maestro que enseña, como imagen real y personal, como amigo, como compañero siempre fiel, como ayuda en todo. El ser humano es capaz de una relación cercana con el Dios encarnado en Jesús, a través de: la razón, la conciencia, la palabra, los gestos, la compañía. Junto a ellas las actitudes de humildad, de contentar al otro, de dejarse acompañar, etc. Dios se queda en el hombre cuando es bien recibido. Esta cercanía genera en el hombre el amor por Dios, y Dios se queda en el hombre. Conjuntamente el amor y la razón experimentan la Presencia de Dios en el ser humano.

(124) CV 12, 1. /... Trabajo grande parece todo -y con razón- porque es guerra contra nosotros mismos; mas comenzándose a obrar, obra Dios tanto en el alma y hácela tantas mercedes, que todo le parece poco cuanto se puede hacer en esta vida. Y pues las monjas hacemos lo más, que es dar la libertad por amor de Dios poniéndola en otro poder, y pasan tantos trabajos, ayunos, silencio, /.../.

(125) CV 32, 3. Cuando yo pienso esto, gusto de las personas que no osan pedir trabajos al Señor, que piensan está en esto el dárselos luego. No hablo en los que lo dejan por humildad, pareciéndoles no serán para sufrirlos; aunque tengo para mí que quien les da amor para pedir este medio tan áspero para mostrarle, le dará para sufrirlos. Querría preguntar a los que por temor no los piden de que luego se los han de dar, lo que dicen cuando suplican al Señor cumpla su voluntad en ellos, o es que lo dicen por decir lo que todos, mas no para hacerlo; esto, hermanas, no sería bien. Mirad que parece aquí el buen Jesús nuestro embajador, y que ha querido intervenir entre nosotros y su Padre, y no a poca costa suya; y no sería razón que lo que ofrece por nosotros dejásemos de hacerlo verdad, o no lo digamos. 
/.../, tener compañía. ¿Pues qué mejor que la del mismo Maestro que enseñó la oración que vais a rezar? Representad al mismo Señor junto con vos y mirad con qué amor y humildad os está enseñando; y creedme, mientras pudiereis, no estéis sin tan buen amigo. Si os acostumbráis a traerle cabe vos, y El ve que lo hacéis con amor y que andáis procurando contentarle, no le podréis -como dicen- echar de vos; no os faltará para siempre; ayudaros ha en todos vuestros trabajos; tenerle heis en todas partes. ¿Pensáis que es poco un tal amigo al lado? (126).

El amor lleva a conocer en profundidad. La razón descubre el ser de Dios, porque el ser humano es imagen y semejanza de Dios. La humanidad de Jesús le identifica con el ser humano, y parece que le obliga, a Jesús, a interceder por los hombres. La cercanía a Jesús y la experiencia de Dios llevan a Teresa a reclamar por la honra de Dios. Esta pedagogía de Teresa pretende hacer entender el Amor de Dios como sobreabundancia, un amor que le lleva a Jesús a la extremosidad del todo. Teresa agradece tanta entrega, y desmesura de Dios; desea hacer entender al hombre que el Padre y el Hijo son Unidad, y eso obliga al Padre. Dios ama al ser humano de tal modo que entrega al Hijo; el Hijo valora tanto al hombre, que obliga al Padre a serlo de todos. Dios se desborda haciéndonos hijos y hermanos, desde el abajamiento.

Mirad, Señor mío, que ya que Vos con el amor que nos tenéis y con vuestra humildad, no se ponga nada delante (en fin, Señor, estáis en la tierra y vestido de ella, pues tenéis nuestra naturaleza), parece tenéis causa alguna para mirar nuestro provecho; mas mirad que vuestro Padre está en el cielo-Vos lo decíses razón que miréis por su honra. Ya que estáis Vos ofrecido a ser deshonrado por nosotros, dejad a vuestro Padre libre; no le obliguéis a tanto por gente tan ruin como yo, que le ha de dar tan malas gracias (127).

\subsection{El Espíritu Santo pone al ser humano bajo la gracia en el mundo (CV 27, 7)}

El amor de Dios al ser humano se muestra en la gracia. La experiencia de oración capacita al ser humano para definirse como hijo, y valorar la filiación como la propia identidad y pertenencia. La razón es capaz, incluso, de "consolar". Después de explicar, con todo lujo de detalles, Teresa se fía de la capacidad del entendimiento humano. El definitivo consuelo en el mundo es ofrecido por la Trinidad: el Padre creando, el Hijo salvando y el Espíritu Santo llevando a plenitud toda la creación.

El Espíritu Santo es el amor entre el Padre y el Hijo, y es el amor de Dios trinitario hacia el ser humano. Un amor que enamora y ata con Dios. El Espíritu es

(126) CV 26, 1. Ahora, pues, tornemos a nuestra oración vocal para que se rece de manera que, sin entendernos, nos lo dé Dios todo junto, y para -como he dicho- rezar como es razón.

La examinación de la conciencia y decir la confesión y santiguaros, ya se sabe ha de ser lo primero. Procurad luego, hija, pues estáis sola, tener compañía. ¿Pues qué mejor que la del mismo Maestro que enseñó /.../.

(127) CV 27, 3. 
el amor que une la Trinidad, y a esta con la Humanidad. El amor en el hombre va llevando a la divinización. El Espíritu Santo atrae y vincula con lazos de amor y provoca, en el ser humano, el deseo de la unión. Esta necesidad de unidad se experimenta en que el amor ata a la razón con Dios, y por ello puede el ser humano llegar a la alabanza mística, donde acontece la plenitud de la unión.

La persona es habitada por el Espíritu Santo. La voluntad del hombre y de la mujer se puede enamorar. El hacer, el querer, todas las funciones de la voluntad, se "afectibizan". La persona se unifica integrando todos sus elementos por el nexo del amor. Así, el Espíritu actúa en el mundo y lleva a cabo la construcción histórica del amor en toda la creación.

¡Oh, válgame Dios!, y que hay aquí en qué os consolar, que por no me alargar más lo quiero dejar a vuestros entendimientos; que por disparatado que ande el pensamiento, entre tal Hijo y tal Padre forzado ha de estar el Espíritu Santo que enamore vuestra voluntad y os la ate tan grandísimo amor, ya que no baste para esto tan gran interés (128).

\section{El ser humano en esperanza}

Continuando en la obra "Camino de Perfección" de Santa Teresa, se desarrollan las ideas siguientes: el amor da a conocer y significa ante el mundo la santidad; la razón comprende y esclarece lo distintivo del cristiano; el amor y la razón plenificados en la santidad, o sea que ambos aspirando a lo definitivo, desde su limitación, experimentan la plenitud; y el espíritu del Señor consumador del ser humano, la historia, y toda la creación.

\subsection{El amor revela la santidad}

Se estudia el amor perfecto: sus elementos, la plenificación a través del fuego, y los efectos que causa en el hombre. Este amor experimentado por el ser humano se desborda y, de ese modo, comunica, ya en este mundo, la esperanza en lo definitivo.

Teresa va a desarrollar algunos elementos del amor perfecto: su transcendencia e intensidad; su capacidad para hacer vivir como salvado y conforme a Cristo; y lo apasionado y sufriente de este amor.

El amor perfecto es el contenido del capítulo sexto de Camino (129). El amor puro espiritual se profesa entre los santos, los hermanos (130). Este amor es don de Dios, que regala a quien ha poseído hasta las entrañas. El amor puro ama todo lo humano, y desde la hermosura de los cuerpos se abre a la alabanza (131). Para el

(128) CV 27, 7.

(129) CV 6, tít. Torna a la materia que comenzo del amor perfecto.

(130) CV 6, 1. /... Tornemos ahora al amor que es bien y lícito nos tengamos, del que digo es puro espiritual. /.../.

(131) CV 6, 4. Podrá ser, hermanas, que os parezca tratar en esto impertinente y que digáis que estas cosas que he dicho ya todas las sabéis. Plega al Señor sea así que lo sepáis de la manera que hace al caso, imprimido en las entrañas; pues si lo sabéis, veréis que no miento en decir que, a quien el Señor llega aquí, tiene este amor. 
contemplativo el amor no es búsqueda del propio provecho (132); el amor humano se hace de mayor intensidad, más verdadero, más apasionado, más provechoso (133). Este amor todo lo soporta, todo lo quiere, todo lo hace eterno (134): acontece en quien posee la sabiduría. El amor y el conocimiento llevan a la persona a la plenitud, a la santidad, a vivir ya atisbos de escatología. El amor perfecto desea que todos lleguen a experimentar este amor pleno. El ser humano que lo vive es: totalmente disponible y servicial, un apasionado del amor, se experimenta ya como salvado, es Cristo quien vive en él (135). En el capítulo siguiente, Teresa trata este amor espiritual (136), costoso, que se sufre, se llora, se reza; es el amor humano que se va plenificando: Es cosa extraña qué apasionado amor es este, /.../ (137). Se presenta en la historia imitando el amor de Jesús, como se descubre en Santa Móni-

Son estas personas que Dios las llega a este estado, almas generosas, almas reales; no se contentan con amar cosa tan ruin como estos cuerpos, por hermosos que sean, por muchas gracias que tengan, bien que place a la vista y alaban al Criador; mas para detenerse en ello, no. Digo "detenerse", de manera que por estas cosas los tengan amor; parecerles hía que aman cosa sin tomo y que se ponen a querer sombra; correrse hían de sí mismos y no tendrían cara, sin gran afrenta suya, para decir a Dios que le aman.

(132) CV 6, 6. Ahora noten que, como el amor, /.../ estas personas perfectas ya todos los tienen debajo de los pies los bienes que en el mundo les pueden hacer /.../ ¿qué provecho, les puede venir de ser amados?

(133) CV 6, 7. Como se les representa esta verdad, de sí mismos se ríen de la pena que algún tiempo les ha dado si era pagada o no su voluntad. /.../. Así que, si no es para provecho de su alma con las personas que tengo dichas - porque ven ser tal nuestro natural que si no hay algún amor luego se cansan- no se les da más ser queridas que no. Pareceros ha que estos tales no quieren a nadie, ni saben, sino a Dios.

Digo que sí aman mucho más, y con más verdadero amor, y con más pasión y más provechoso amor; en fin, es amor. Y estas tales almas son siempre aficionadas a dar mucho más que no a recibir; aun con el mismo Criador les acaece esto. Digo que merece este nombre de amor, que esotras aficiones bajas le tienen usurpado el nombre.

(134) CV 6, 8. También os parecerá que si no aman por las cosas que ven, que ¿a qué se aficionan? Verdad es que lo que ven aman y a lo que oyen se aficionan; mas esas cosas que ven son estables. Luego estos, si aman, pasan por los cuerpos y ponen los ojos en las almas y miran si hay qué amar; y si no lo hay y ven algún principio o disposición para que, si cavan, hallarán oro en esta mina, si la tienen amor, no les duele el trabajo; ninguna cosa se les pone delante que de buena gana no la hiciesen por el bien de aquel alma, porque desean durar en amarla, y saben muy bien que si no tiene bienes y ama mucho a Dios, que es imposible. Y digo "que es imposible", aunque más la obligue y se muera queriéndola, y la haga todas las buenas obras que pueda, y tenga todas las gracias de naturaleza juntas; no tendrá fuerza la voluntad, ni la podrá hacer estar con asiento. Ya sabe y tiene experiencia de lo que es todo; no le echarán dado falso. Ve que no son para en uno y que es imposible durar a quererse el uno al otro; porque es amor que se ha de acabar con la vida, si el otro no va guardando la ley de Dios, y entiende que no le ama y que han de ir a diferentes partes.

(135) CV 6, 9. Y este amor que solo acá dura, alma de estas a quien el Señor ya ha infundido verdadera sabiduría, no le estima en más de lo que vale, ni en tanto; porque para los que gustan de gustar de cosas del mundo, deleites y honras y riquezas, algo valdrá si es rico, o tiene partes para dar pasatiempo y recreación; mas quien todo esto aborrece ya, poco o nonada se le dará de aquello. Ahora, pues, aquí -si tiene amor- es la pasión para hacer esta alma ame a Dios para ser amada de él, porque -como digo- sabe que no ha de durar en quererla. Es amor muy a su costa; no deja de poner todo lo que puede porque se aproveche; perdería mil vidas por un pequeño bien suyo. ¡Oh precioso amor, que va imitando al capitán del amor, Jesús, nuestro bien!

(136) CV 7, tít. En que trata de la misma materia de amor espiritual, y da algunos avisos para ganarle.

(137) CV 7, 1. /... Es - como he dicho- amor sin poco ni mucho de interés propio; todo lo que desea y quiere es ver rica aquella alma de bienes del cielo. Esta es voluntad, y no estos quereres de por acá desastrados -aun no digo los malos- que de esos Dios nos libre. 
ca y San Agustín (138). El amor perfecto se muestra en saber sufrir las faltas de los otros, es signo de la fraternidad y de la santidad del Cuerpo, la Iglesia (139).

Teresa explica cómo el amor de Dios lleva al ser humano a la plenitud, purificándole por el fuego hasta la muerte. El amor del Señor, al pedirlo, concede la perfección interior (140) de cada persona y de toda la Iglesia (141). El amor y el deseo de Dios, pueden ser tan intensos que la condición humana no lo soporte, y lleve incluso a la muerte; puerta hacia la vida definitiva. Quien ama tan perfectamente, puede traspasar el umbral y llegar al gozo de Dios (142). El ser humano se consume y pasa a lo definitivo a través del amor, aunque no lo entienda. Abrasándose, el ser humano ilumina y da a conocer la santidad:

Entiende que, sin ruido de palabras, le está enseñando este Maestro divino, suspendiendo las potencias, porque entonces antes dañarían que aprovecharían si obrasen. Gozan sin entender cómo gozan; está el alma abrasándose en amor, y no entiende cómo ama; conoce; que goza de lo que ama, y no sabe como lo goza; bien entiende que no es gozo que alcanza el entendimiento a desearle; abrázale la voluntad sin entender cómo; mas en pudiendo entender algo, ve que no es este bien que se puede merecer con todos los trabajos que se pasasen juntos por ganarle en la tierra. Es don del Señor de ella y del cielo, que en fin, da como quien es. Esta, hijas, es contemplación perfecta (143).

Cuando la persona se deja instruir llega a conocer que el amor le hace gozar; y entiende que ese gozo es superior a todo lo deseado. El amor abraza, envuelve a

(138) CV 7, 4. Torno otra vez a decir que se parece y va imitando este amor al que nos tuvo el buen amador Jesús y así aprovechan tanto; porque abrazan todos los trabajos, y que los otros, sin trabajar, se aprovechasen de ellos. Así ganan muy mucho los que tienen su amistad; y crean que, o los dejarán de tratar -con particular amistad digo-o acabarán con nuestro Señor que vayan por su camino, pues van a una tierra, como hizo Santa Mónica con San Agustín./.../.

(139) CV 7, 7. Procurar también holgaros con las hermanas cuando tienen recreación con necesidad de ella y el rato que es de costumbre, aunque no sea a vuestro gusto; que yendo con consideración, todo es amor perfecto. /.../. sientan mucho cualquiera falta, si es notoria, que veáis en la hermana. Y aquí se muestra y ejercita bien el amor en sabérsela sufrir y no se espantar de ella, /.../.

(140) CV 2, 7. /../ por amor del Señor, pues son nuestras armas la santa pobreza y lo que al principio de la fundación de nuestra Orden tanto se estimaba y guardaba en nuestros santos padres (que me ha dicho quien lo sabe, que de un día para otro no guardaban nada), ya que en tanta perfección en lo exterior no se guarde, en lo interior procuremos tenerla. /.../.

(141) CV 3, 6. /.../ Así que os pido, por amor del Señor, pidáis a su Majestad nos oiga en esto. Yo, aunque miserable, lo pido a su Majestad, pues es para gloria suya y bien de su Iglesia, que aquí van mis deseos.

(142) CV 19, 8. La otra propiedad del agua es que harta y quita la sed; porque sed me parece a mí quiere decir deseo de una cosa que nos hace gran falta, que si del todo nos falta nos mata. Extraña cosa es que si nos falta nos mata y si nos sobra nos acaba la como se ve morir muchos ahogados. ¡Oh Señor mío, y quién se viese tan engolfada en este agua viva que se le acabase la vida! Mas, ¿no puede ser esto? Sí, que tanto puede crecer el amor y deseo de Dios, que no lo pueda sufrir el sujeto natural, y así ha habido personas que han muerto. Yo sé de una que si no la socorriera Dios presto con esta agua viva tan en gran abundancia, que casi la sacaba de sí con arrobamientos. Digo que casi la sacaban de sí, porque aquí descansa el alma. Parece que, ahogada de no poder sufrir el mundo, resucita en Dios, y su Majestad la habilita para que pueda gozar lo que -estando en sí- no pudiera sin acabarse la vida.

(143) CV 25, 2. 
todo el ser; sin que la razón sepa la manera. Esta experiencia de amor de Dios, es superior a todo lo que la persona pueda ofrecer para ganarlo. La imagen del fuego que abrasa, purifica, y devora significa espectacularmente el camino para la unión con el Amado. El amor es la experiencia desbordante de lo humano; es la gracia que habitando en el hombre, le hace vivir la salvación. La cercanía de Dios, la gracia, salva al hombre abrasándole en amor. Esta unión de gracia y salvación se experimenta en la contemplación. La razón no queda anulada, es capaz de descubrir que el amor es el fundamento de la existencia, y eso la hace gozar. El amor desborda la razón, y la razón sabe que ama. El amor y la razón juntas en contemplación ardiente y apasionada.

La presencia amorosa de Dios se adueña del ser humano, lo posee, y lo conforma a Cristo (144). El amor divino es fuego que se extiende, se contagia, purifica, ilumina, atrae, consume y lleva a la otra vida:

Entiéndase mucho esto que queda dicho, porque, aunque parece oscuro, se entenderá a quien quisiere obrarlo. Así que caminan por mar; y pues tanto nos va no ir tan despacio, hablemos un poco de cómo nos acostumbraremos a tan buen modo de proceder. Están más seguros de muchas ocasiones; pégase más presto el fuego del amor divino, porque con poquito que soplen con el entendimiento, como están cerca del mismo fuego, con una centellica que le toque se abrasará todo. Como no hay embarazo de lo exterior, estáse sola el alma con su Dios; hay gran aparejo para encenderse (145).

El amor de Dios se imprime en la persona, especialmente, con la comunión; tanto la espiritual como la encarnada en la comunidad. Siempre que el ser humano se recoge y hace hueco en sí, el amor de Dios se aposenta, y habita en el ser humano. Es un habitar intenso como el fuego (146).

Teresa desarrolla algunos efectos que causa el amor de Dios en el hombre: un nuevo ser; el resplandecer ante el mundo -dándose a entender cuando se comunica y se pide-; y finalmente se asocia con la reverencia filial, entendida como el don de temor de Dios.

El amor de Dios transforma la realidad humana radicalmente: así Pablo y Magdalena llegan a estar "enfermos de amor". La fuerza del amor se expande, y la medida de este influjo e irradiación es la capacidad humana para el amor. El amor se entiende; a unos les cuesta más que a otros; se entiende en la medida de la capacidad del sujeto. El amor de Dios "siempre se entiende".

Quien[es] de veras aman a Dios, todo lo bueno aman, todo lo bueno quieren, todo lo bueno favorecen, todo lo bueno loan, con los buenos se juntan siempre

(144) CV 26, 1.

(145) CV 28, 8.

(146) CV 35, 1./../ podéis comulgar espiritualmente, que es de grandísimo provecho, y hacer lo mismo de recogeros después en vos, que es mucho lo que se imprime el amor así de este Señor; porque aparejándonos a recibir, jamás por muchas maneras deja de dar que no entendemos. Es llegarnos al fuego que -aunque le haya muy grande- si estáis desviados y escondéis las manos, mal os las podéis calentar, aunque todavía da más calor que no estar adonde no haya fuego. /.../. 
y los favorecen y defienden; no aman sino verdades y cosa que sea digna de amar. ¿Pensáis que es posible, quien muy de veras ama a Dios, amar vanidades? Ni puede, ni riquezas, ni cosas del mundo, de deleites, ni honras, ni tiene contiendas, ni envidias; todo porque no pretende otra cosa sino contentar al Amado. Andan muriendo porque los ame, y así ponen la vida en entender cómo le agradarán más.

¿Esconderse? ¡Oh, que el amor de Dios -si de veras es amor-es imposible! Si no, mirad un San Pablo, una Magdalena; en tres días el uno comenzó a entenderse que estaba enfermo de amor; este fue San Pablo. La Magdalena desde el primer día, ¡y cuán bien entendido! Que esto tiene, que hay más o menos, y así se da a entender, como la fuerza que tiene el amor: si es poco, dase a entender poco, y si es mucho, mucho; mas poco o mucho, como haya amor de Dios, siempre se entiende (147).

El amor contemplativo es transmisible, se da a entender, y resplandece. Desborda, incluso, la capacidad del conocimiento, buscando nuevos cauces de expresión de lo inexpresable. Es bien elocuente la imagen del resplandor del fuego (148). El amor "escatológico" da felicidad, serenidad, gozo, seguridad en la acción de Dios en la criatura (149). El amor contemplativo porque se entiende se puede comunicar. Es un amor creciente, alaba desmedidamente, está vigilante, e incluso anhela perder la vida. Teresa concibe este tipo de amor de modo entendible; manifiesto y no encubierto, se conoce y se comunica (150). Este amor contemplativo se ha de pedir para disfrutarlo en esta vida, y sobre él vamos a ser juzgados. Es un juicio confiable porque se está en el terreno de quien es amor, a quien se ha amado y de quien ama a cada uno. Es un amor que solo da ganancia (151).

El amor definitivo va parejo con el temor. Es un amor sabroso que se desea poseer: se asemeja a la gloria, y es un profundo anhelo humano (152). El temor de Dios es consecuencia del amor: el hombre se esfuerza y confía en Dios; y porque

(147) $\mathrm{CV} 40,3$

(148) CV 40, 4. Mas de lo que ahora tratamos más, que es de los engaños e ilusiones que hace el demonio a los contemplativos, no hay poco; siempre es el amor mucho -o ellos no serán contemplativos-, y así se da a entender mucho y de muchas maneras. Es fuego grande, no puede sino dar gran resplandor. /.../.

(149) CV 40, 5. Mas si sentís este amor de Dios que tengo dicho y el temor que ahora diré, andad alegres y quietas, que por haceros turbar el alma para que no goce tan grandes bienes, os pondrá el demonio mil temores falsos y hará que otros os los pongan. /.../.

(150) CV 40, 7.

(151) CV 40, 8. Plega a su Majestad nos le dé antes que nos saque de esta vida, porque será gran cosa a la hora de la muerte ver que vamos a ser juzgados de quien habemos amado sobre todas las cosas. Seguras podremos ir con el pleito de nuestras deudas; no será ir a tierra extraña sino propia, pues es a la de quien tanto amamos y nos ama. Acordaos, hijas mías, aquí de la ganancia que trae este amor consigo y de la pérdida en no le tener, que nos pone en manos del tentador, en manos tan crueles, manos tan enemigas de todo bien y tan amigas de todo mal.

(152) CV 41, 1. ¡Cómo me he alargado! Pues no tanto como quisiera, porque es cosa sabrosa hablar en tal amor, ¿qué será tenerle? El Señor me le dé, por quien su Majestad es.

Ahora vengamos al temor de Dios. Es cosa también muy conocida de quien le tiene y de los que le tratan. /.../. Mas cuando ya llega el alma a contemplación -que es de lo que más ahora aquí tratamos-, el temor de Dios también anda muy al descubierto, como el amor; no va disimulado aun en lo exterior. /.../. 
sabe de su fragilidad se muestra temeroso para no caer. El amor vigilante regala sosiego y quietud, y así se evita la irritación (Cf. Flp 2, 12-16) (153).

\subsection{La razón esclarece la santidad}

En Teresa, la razón ilumina la santidad porque es capacidad para discernir e ir a lo profundo, y porque anhela el goce de la felicidad.

La razón completa lo humano pues, contando con la limitación y la flaqueza, discierne lo bueno para el ser humano. La condición creatural es base para caminar hacia la plenitud (154). La razón es impulso para ir a lo profundo, es instrumento para caminar desde la hondura hacia la altura. La razón añora lo definitivo porque, después de conocer todo el bien recibido, quiere dejar la tierra para vivir en cercanía lo que acá ha atisbado. La razón anhela la plenitud, la persigue buscando lo escatológico (155). La razón comprende que el amor de Dios se abaje a la medida del ser humano; la presencia de Dios en el ser humano da claridad, hace diáfana la oscuridad. La razón llega a mofarse del tiempo de tinieblas, se ríe de las crisis porque ahora conoce la luz y entiende que la inmensidad se sumerja en la pequeñez. Esta razón contemplativa es la que puede ocasionar la transformación y entrar en una racionalidad nueva:

Reiránse de mí, por ventura, y dirán que bien claro se está esto, y tendrán razón, porque para mí fue oscuro algún tiempo. Bien entendía que tenía alma; mas lo que merecía esta alma y quién estaba dentro de ella si yo no me tapara los ojos con las vanidades de la vida para verlo, no lo entendía. Que -a mi parecer- si como ahora entiendo que en este palacio pequeñito de mi alma cabe tan gran Rey, que no le dejara tantas veces solo; alguna me estuviera con Él y más procurara que no estuviera tan sucia. Mas, qué cosa de tanta admiración, quien hinchiera mil mundos y muy muchos más con su grandeza, encerrarse en

(153) CV 41, 9. Veis aquí cómo con estas dos cosas -amor y temor de Dios- podemos ir por este camino sosegados y quietos, aunque, como el temor ha de ir siempre delante, no descuidados, que esta seguridad no la hemos de tener mientras vivimos, porque sería gran peligro. Y así lo entendió nuestro Enseñador, cuando en el fin de esta oración dice a su Padre estas palabras, como quien entendió bien eran menester.

(154) CV 7, 3. Estotra voluntad no es así. Aunque con la flaqueza natural se sienta algo de presto, luego la razón mira si es bien para aquel alma, si se enriquece más en virtud y cómo lo lleva, el rogar a Dios la dé paciencia y merezca en los trabajos. Si ve que la tiene, ninguna pena siente, antes se alegra y consuela; bien que lo pasaría de mejor gana que vérselo pasar, si el mérito y ganancia que hay en padecer pudiese todo dársele, mas no para que se inquiete ni desasosiegue.

(155) CV 27, 1. "Padre nuestro que estás en los cielos". ¡Oh Señor mío, cómo parecéis Padre de tal Hijo y cómo parece vuestro Hijo hijo de tal Padre! ¡Bendito seáis por siempre jamás! No fuera al fin de la oración esta merced, Señor, tan grande. En comenzando, nos henchís las manos y hacéis tan gran merced que sería harto bien henchirse el entendimiento para ocupar de manera la voluntad que no pudiese hablar palabra.

¡Oh, qué bien venía aquí, hijas, contemplación perfecta! ¡Oh, con cuánta razón se entraría el alma en sí para poder mejor subir sobre sí misma a que le diese este santo Hijo a entender qué cosa es el lugar a donde dice que está su Padre, que es en los cielos! Salgamos de la tierra, hijas mías, que tal merced como esta no es razón se tenga en tan poco, que después que entendamos cuán grande es, nos quedemos en la tierra. 
una cosa tan pequeña! A la verdad, como es Señor, consigo trae la libertad, y como nos ama, hácese a nuestra medida (156).

La razón sopesa y discierne la posibilidad de transformación a una lógica que piense desde una racionalidad escatológica; es decir, vivir como resucitados (157).

Para Teresa, la razón camina al encuentro de la felicidad, persigue la unión con el Esposo. Se recorre este itinerario estimulada por el deleite; se entrega la libertad por una mayor ganancia; se comprende la gracia y se evita la tentación.

La razón está estimula al goce y al deleite con el Esposo (158); porque en Él está la felicidad, y porque no necesita más argumentaciones cuando disfruta de la experiencia (159). La razón busca la gloria del Padre que está en el cielo; allí el ser humano se encontrará con Él. Desde acá ha de procurar mirar, cuidar, proteger, defender y mostrar la gloria y la honra del Padre de Jesús (160). La razón descubre razonable la libre entrega a Dios; solo la libertad del hombre puede dar cabida a Dios dentro de su ser. Dios no invade, solo entra si el hombre se ha entregado por completo a Él (161).

(156) CV 28, 11.

(157) CV 34, 5. Es como si entra un criado a servir; tiene cuenta con contentar a su señor en todo, mas él está obligado a dar de comer al siervo mientras está en su casa y le sirve, salvo si no es tan pobre, que no tiene para sí ni para él. Acá cesa esto: siempre es y será rico y poderoso. Pues no sería bien andar el criado pidiendo de comer, pues sabe tiene cuidado su amo de dárselo y le ha de tener. Con razón le dirá que se ocupe él en servirle y en cómo le contentar, que por andar ocupado el cuidado en lo que no le ha de tener no hace cosa a derechas.

Así que, hermanas, tenga quien quisiere cuidado de pedir ese pan; nosotras pidamos al Padre Eterno merezcamos recibir el nuestro pan celestial de manera que, ya que los ojos del cuerpo no se pueden deleitar en mirarle por estar tan encubierto, se descubra a los del alma y se le dé a conocer; que es otro mantenimiento de contentos y regalos y que sustenta la vida.

(158) CV 22, 7. Sí, llegaos a pensar y entender, en llegando, con quién vais a hablar o con quién estáis hablando. En mil vidas de las nuestras no acabaremos de entender cómo merece ser tratado este Señor, que los ángeles tiemblan delante de él. Todo lo manda, todo lo puede; su querer es obrar. Pues razón será, hijas, que procuremos deleitarnos en estas grandezas que tiene nuestro Esposo, y que entendamos con quién estamos casadas, qué vida hemos de tener. ¡Oh, válgame Dios!, pues acá, cuando uno se casa, primero sabe con quién, quién es y qué tiene; nosotras, ya desposadas, antes de las bodas, que nos ha de llevar a su casa -pues acá no quitan estos pensamientos a las que están desposadas con los hombres-, ¿por qué nos han de quitar que procuremos entender quién es este hombre, y quién es su padre, y qué tierra es esta adonde me ha de llevar, y qué bienes son los que promete darme, qué condición tiene, cómo podré contentarle mejor, en qué le haré placer, y estudiar cómo haré mi condición que conforme con la suya? Pues si una mujer ha de ser bien casada, no le avisan otra cosa sino que procure esto, aunque sea hombre muy bajo su marido.

(159) CV 22, 8. Pues, Esposo mío, ¿en todo han de hacer menos caso de Vos que de los hombre? Si a ellos no les parece bien esto, dejen os vuestras esposas que han de hacer vida con Vos. Es verdad que es buena vida. Si un esposo es tan celoso que quiere no trate con nadie su esposa, ¡linda cosa es que no piense en como le hará este placer y la razón que tiene de sufrirle y de no querer que trate con otro, pues en él tiene todo lo que puede querer!

Esta es oración mental, hijas mías, entender estas verdades. Si queréis ir entendiendo esto y rezando vocalmente, muy enhorabuena. No me estéis hablando con Dios y pensando en otras cosas, que esto hace no entender qué cosa es oración mental. Creo va dado a entender; plega el Señor lo sepamos obrar, amén

(160) CV 27, 3.

(161) CV 28, 12. Cuando un alma comienza - por no la alborotar de verse tan pequeña para tener en sí cosa tan grande- no se da a conocer hasta que va ensanchándola poco a poco, conforme a lo que más ha menester para lo que ha de poner en ella. Por esto digo que trae consigo la libertad, pues 
La razón ilumina al contemplativo para estar vigilante; cobrar conciencia de filiación, y orar para no caer en la tentación. La razón pide insistentemente la liberación del mal. A mayor cercanía de Dios, mayor temor de perderlo y mayor oración y petición de gracia (162). La razón se admira de lo novedoso, extraordinario y no de lo común, aunque sea más escandaloso (163).

La síntesis de este segundo apartado se expresa afirmando que la plenificación de la razón acontece en la unión con el amado.

\subsection{Amor y razón plenificados en la santidad}

Teresa presenta, ya en esta vida, la plenificación del amor y de la razón, desde su propia experiencia de encuentro místico con Dios. El conocimiento es desbordado por el amor; el amor se vive con conocimiento; y ambos perijoréticamente plenifican al hombre.

El amor lleva al conocimiento desbordándolo. La razón valora el amor como perfección, y atisba signos de la presencia de Dios en el hombre.

El conocimiento es desbordado cuando la razón empequeñecida no entiende los valores: el compartir, la pobreza, la filiación y la fraternidad. La razón humana busca estratagemas para justificar el propio interés, pero puede dar un paso mayor y, desde la libertad y las opciones, asumir en sí misma la voluntad de Dios. Esta nueva racionalidad se hace razón escatológica, que ya acá puede conocer lo definitivo. La razón contemplativa comprende y entiende como razonable lo metarracional, se abre

tiene el poder de hacer grande este palacio todo. El punto está en que se le demos por suyo con toda determinación, y le desembaracemos para que pueda poner y quitar como en cosa propia. Y tiene razón su Majestad, no se lo neguemos. Y como Él no ha de forzar nuestra voluntad, toma lo que le damos; mas no se da a Sí del todo hasta que nos damos del todo.

Esto es cosa cierta y, porque importa tanto, os lo acuerdo tantas veces; ni obra en el alma, como cuando del todo, sin embarazo, es suya; ni sé cómo ha de obrar: es amigo de todo concierto. Pues si el palacio henchimos de gente baja y de baratijas, ¿cómo ha de caber el Señor con su corte? Harto hace de estar un poquito entre tanto embarazo.

(162) CV 38, 2. Creed, hermanas, que los soldados de Cristo, que son los que tienen contemplación y tratan de oración, no ven la hora que pelear; nunca temen mucho enemigos públicos; ya los conocen y saben que, con la fuerza que en ellos pone el Señor, no tienen fuerza, y que siempre quedan vencedores y con gran ganancia; nunca los vuelven el rostro. Los que temen, y es razón teman y siempre pidan los libre el Señor de ellos, son unos enemigos que hay traidores, unos demonios que se transfiguran en ángel de luz; vienen disfrazados. Hasta que han hecho mucho daño en el alma no se dejan conocer, sino que nos andan bebiendo la sangre y acabando las virtudes y andamos en la misma tentación y no lo entendemos. De estos pidamos, hijas, y supliquemos muchas veces en el Paternóster que nos libre el Señor y que no consienta andemos en tentación, que nos traigan engañadas, que se descubra la ponzoña, que no os escondan la luz y la verdad. ¡Oh, con cuánta razón nos enseña nuestro buen Maestro a pedir esto y lo pide por nosotros!

(163) CV 39, 7. Cosa extraña es esta, ¡como si para los que no van por camino de oración no tentase el demonio!, y que se espanten más todos de uno que engaña de los que van más llegados a perfección, que de cien mil que ven en engaños y pecados públicos, que no hay que andar a mirar si es bueno o malo, porque de mil leguas se entiende es Satanás. A la verdad, tienen razón, porque son tan poquísimos a los que engaña el demonio de los que rezaren el Paternóster como queda dicho, que, como cosa nueva y no usada, da admiración; que es cosa muy de los mortales pasar fácilmente por lo continuo que ven y espantarse mucho de lo que es muy pocas veces o casi ninguna; y los mismos demonios los hacen espantar, porque les está a ellos bien, que pierden muchos por uno que se llega a la perfección. 
a una nueva lógica. Desde esta racionalidad, el amor historificado se hace amor extremo. Es el mejor amor, y fue el medio "admirable" que Jesús eligió (Jn 13, 1). Este amor se eterniza, y en la vida plena, la que no tiene término, se recibe mucho más de lo dado (164).

La razón admite que el amor es patrimonio de los perfectos, que lo viven unido al conocimiento. Los perfectos detectan las señales, los signos, de la presencia de Dios; ellos ven, oyen y entienden, en medio del mundo, la sustentadora acción de Dios. El ser humano vive en esperanza porque está protegido por dos castillos: el del amor, que es comprendido por la razón como el estar en gracia, y el castillo del temor, relacionado con la sabiduría, que es entendido por el amor como la filiación. La defensa, la fortaleza fundamental del ser humano, es esta conjugación entre el amor y la razón reverencial y respetuosa. Teresa de fondo está aludiendo a un problema, que en sus obras los censores corrigen continuamente; se trata de la polémica protestante respecto a la certeza y la seguridad que el hombre puede o no tener de estar en gracia. Ella afirma la posibilidad desde el amor. El amor hace que el ser humano, habitado por el amor de Dios, esté en gracia. El amor es la realización del ser humano:

Diréisme que en qué veréis que tenéis estas dos virtudes tan grandes, y tenéis razón, porque cosa muy cierta y determinada no la puede haber; porque siéndolo de que tenemos amor, lo estaremos de que estamos en gracia. Mas mirad, hermanas, hay unas señales que parece los ciegos las ven, no están secretas: aunque no queráis entenderlas, ellas dan voces que hacen mucho ruido, porque no son muchos los que con perfección las tienen, y así se señalan más. ¡Como quien no dice nada: amor y temor de Dios! Son dos castillos fuertes, desde donde se da guerra al mundo y a los demonios (165).

La frase de Teresa “... con tanta razón amamos” ratifica el amor con sabiduría. La imagen de la persona ausente es un anticipo de su presencia. Cristo está viniendo a encontrarse con cada uno; la cercanía de la parusía. Por otro lado, Cristo ya está realmente presente en la Eucaristía. En el proceso de crecimiento interior, la persona va experimentando el deseo de ver a Dios. La autora hace una crítica a quienes en su

(164) CV 33, 1. Pues entendiendo -como he dicho- el buen Jesús cuán dificultosa cosa era esta que ofrece por nosotros, conociendo nuestra flaqueza; y que muchas veces hacemos entender que no entendemos cuál es la voluntad del Señor -como somos flacos y Él tan piadoso- y que era menester medio [...]; porque dejar de dar lo dado vio que en ninguna manera nos conviene, porque está en ello toda nuestra ganancia. Pues cumplirlo, vio ser dificultoso, porque decir a un regalado y rico, que es la voluntad de Dios que tenga cuenta con moderar su plato, para que coman otros siquiera pan, que mueren de hambre, sacarán mil razones para no entender esto si no a su propósito. Pues decir a un murmurador que es la voluntad de Dios querer tanto para su prójimo como para sí, no lo puede poner a paciencia ni basta razón para que lo entienda. Pues decir a un religioso, que está mostrado a libertad y a regalo, que ha de tener cuenta con que ha de dar ejemplo, /.../. Pues visto el buen Jesús la necesidad, buscó un medio admirable adonde nos mostró el extremo de amor que nos tiene, y en su nombre y en el de sus hermanos, pidió esta petición: "El pan nuestro de cada día, dánoslo hoy, Señor". Entendamos, hermanas, por amor de Dios, esto que pide nuestro buen Maestro, que nos va la vida en no pasar de corrida por ello, y tened en muy poco lo que habéis dado, pues tanto habéis de recibir.

(165) CV 40, 2. 
afán reformador han llegado a suprimir las imágenes, tan necesarias para la representación y la evocación. El amor necesita representación, se ama a Jesús con la razón y con razón (166).

En Dios el amor y el conocimiento están unidos. El amor y la razón se relacionan perijoréticamente; se interrelacionan en un modo de pensar nuevo, en una racionalidad apasionada como la descubierta en Teresa. El deseo de verse y encontrarse con el Amado, genera en el ser humano el "tenerle amor"; y esto trae como consecuencia que Dios tenga motivos, razón, para consentir que Jesucristo esté presente y actuante en la historia. El amor del ser humano será la razón para que el Padre y el Hijo por el Espíritu, siga actuando en cada persona, en la historia, y todos los días hasta el fin. La presencia de Dios va plenificando su obra amorosa. El amor logra que el Señor se quede con el hombre. La razón pide y entiende los motivos por los cuales la presencia de Jesús se hace real en el mundo. El Esposo vela por la esposa, cuida desmedidamente de la Iglesia, por y a pesar de toda su flaqueza. La presencia de Jesús, en un ser humano y en la comunidad, es ya anticipo de lo definitivo, es la escatología cumpliéndose

Pues mirad, hermanas, que si a los principios no os hallareis bien -que podrá ser, porque os pondrá el demonio apretamiento de corazón y congoja, porque sabe el daño grande que le viene de aquí- haraos entender que halláis más devoción en otras cosas y aquí menos. No dejéis este modo; aquí probará el Señor lo que le queréis.

Acordaos que hay pocas almas que le acompañen y le sigan en los trabajos; pasemos por Él algo, que su Majestad os lo pagará. Y acordaos también qué de personas habrá que no solo quieran no estar con Él, sino que con descomedimiento le echen de sí; pues algo hemos de pasar para que entienda le tenemos deseo de ver. Y pues todo lo sufre y sufrirá por hallar sola un alma que le reciba y tenga en sí con amor, sea esta la vuestra; porque a no haber ninguna, con razón no le consintiera quedar el Padre Eterno con nosotros; sino que es tan amigo de amigos y tan señor de sus siervos, que, como ve la voluntad de su buen Hijo, no le quiere estorbar obra tan excelente y adonde tan cumplidamente muestra el amor que tiene a su Padre (167).

3.4. El espíritu del Señor consumador del ser humano, la historia y toda la creación (CV 38, 1)

La esperanza salvadora del ser humano es el Dios trinitario. El hombre es capaz de reconocer la limitación y la precariedad humana; y, desde esta realidad, el amor y la razón descubren la necesidad de transcendencia.

(166) CV 34, 11. Si esto habéis de pedir mirando una imagen de Cristo que estamos mirando, bobería me parece dejar la misma persona por mirar el dibujo. /.../. Para cuando está ausente la misma persona, o quiere darnos a entender lo está con muchas sequedades, es gran regalo ver una imagen de quien con tanta razón amamos. A cada cabo que volviésemos los ojos, la querría ver. ¿En qué mejor cosa, ni más gustosa a la vista, la podemos emplear que en quien tanto nos ama y en quien tiene en sí todos los bienes? ¡Desventurados estos herejes, que han perdido por su culpa esta consolación con otras!

(167) CV 35, 2. 
Teresa sabe que el ser humano en camino hacia la perfección es capaz de, asumiendo sus límites que son sus propiedades y posesiones, ir más allá de sí mismo. En esta desmesura se entiende que los perfectos pidan más trabajos, sufrimientos, servicios; y no deseen ser liberados de ellos; porque de este modo se sigue creciendo en capacidad receptora de la gracia; se va conformando a Cristo. Ayudarle en la pasión, va completando lo que falta a todo el Cuerpo para la resurrección.

Esta dinámica es posible en el hombre por el Espíritu del Señor que, habitando el corazón humano, puede producir el efecto contrario al esperado en la lógica mundana. El ser humano contemplativo está dispuesto y preparándose para un combate; no es pasividad sino una acción sostenida y de aguante activo.

El espíritu del Señor es comprendido desde la razón humana como la presencia del mismo Jesús en cada persona; una persona así habitada, está capacitada para amar todo, porque todo lo recibe de las manos de Dios. El amor en el ser humano va encaminándole hacia la divinización

El espíritu del Señor hace amar lo no amable; los trabajos y sufrimientos; las tentaciones como ocasión de fortalecimiento; las persecuciones por causa del Reino; las pequeñas peleas y batallas cotidianas donde se resuelve el gran drama de la existencia humana. Por todo ello, la razón y el amor capacitan para asumir lo creatural y llevarlo a perfección; como lo hizo el Hijo por encargo del Padre y por la fuerza del Espíritu.

Grandes cosas tenemos aquí, hermanas, que pensar y que entender, pues lo pedimos. Ahora mirad que tengo por muy cierto los que llegan a la perfección que no piden al Señor los libre de los trabajos ni de las tentaciones ni persecuciones y peleas, que este es otro efecto muy cierto y grande de ser espíritu del Señor, y no ilusión, la contemplación y mercedes que su Majestad les diere; porque -como poco ha dije- antes los desean y los piden y los aman. Son como los soldados que están más contentos cuando hay más guerra, porque esperan salir con más ganancia; si no la hay, sirven con su sueldo, mas ven que no pueden medrar mucho (168).

\section{A MODO DE SÍNTESIS Y CONCLUSIONES}

El acercamiento a la obra "Camino de Perfección", desde una perspectiva antropológica y teniendo en cuenta la relación razón y amor, ha conducido a desvelar algunos aspectos importantes del pensamiento teológico de Santa Teresa. Hay que tener en cuenta que es un primer acercamiento a una gran autora y a esta importante obra, por ello no deja de ser una gran pretensión el poder hacer ciertas afirmaciones. Por ello se descubre la necesidad de mayor estudio y profundización y lo que se ofrece es una pequeña aproximación pendiente de ulteriores investigaciones y estudios.

De modo sintético puede decirse que la razón cimenta al amor y el amor es el resultado del conocimiento desde una perspectiva pneumatológica en el proceso

(168) CV 38, 1. 
histórico de cada hombre. En mi humilde opinión Teresa resuelve la relación razón y amor como RACIONALIDAD APASIONADA en el Espíritu Santo.

Santa Teresa de Jesús en la obra "Camino de Perfección" ha ido vertiendo sus ideas respecto a la realidad de todo lo humano. Lo hace de un modo experiencial y sin atenerse a las normas de uso de los grandes conceptos en su época. Desde la perspectiva indicada podemos detectar tres grandes temas latentes en su escrito: el ser humano creado, en proceso y en esperanza en el mundo.

Cuando habla del ser humano como criatura, lo primero que conviene resaltar es su afirmación de que el amor es la experiencia de Dios en el mundo. En segundo lugar que la razón participa en la relación creativa y/o destructiva. Y que el binomio amor y razón es realidad creatural, y el mismo binomio intercambiado, razón y amor, participan en toda la realidad, incluido el pecado.

A continuación Teresa se centra en el ser humano como realidad procesual y en camino en el mundo. Ella otorga a la razón la capacidad de entender la salvación; al amor la potencia de actualizar la salvación; y finalmente, al tratar juntos razón y amor, muestra cómo ambos elementos constitutivos de lo humano, pueden ir liberándose conjuntamente.

El tercer tema antropológico que se aborda es la realidad humana viviendo en esperanza en el mundo. Desde esta perspectiva el amor revela la santidad; la razón la esclarece; y juntos, amor y razón, son plenificados en la santidad.

Resumiendo cada uno de los epígrafes, se puede intentar sintetizar su pensar del siguiente modo.

Teresa defiende que el amor de Dios crea, es ardiente y se da conocer. El amor humano potencia la realidad personal; señala como, incluso en el dolor, el amor lleva al conocimiento ("saber sufrir") y la razón aprende a asumir todo lo humano. El amor mira a lo duradero y descubre la limitación humana. Y el amor divino busca el servicio, es definitivo. A este amor se llega por el conocimiento en profundidad.

Porque la razón es realidad creada, ha de asumir la creatividad y la destructividad como elementos propios. Por eso es posible una determinada racionalidad que es nueva en cuanto desborda los criterios mundanos. Detrás se encuentra una concepción antropológica unitaria e integral expresada en la identificación entre oración vocal y mental. La razón reconoce su creaturalidad, también su incapacidad; pero se rebela porque anhela la transcendencia.

Cuando se interrelacionan amor-razón creaturales y razón-amor empecatados, Teresa revela dos cosas importantes. Una es la desproporción en la relación Dios y hombre que se traduce, paradójicamente, en amistad. La razón descubre que Dios al entregar todo pide al ser humano la correspondencia; y el amor posibilita que todo lo que se recibe sea ocasión de perfeccionamiento para el hombre. El otro aspecto importante es la reversibilidad entre el conocimiento y el amor en la relación entre el hombre y Dios. Esto acontece porque la razón es imprescindible para la relación amistosa; es decir, se requiere entender lo que se dice al amigo.

Este primer epígrafe ha tratado el hombre como criatura, y se resuelve apelando a la actividad creadora del espíritu de Dios que se manifiesta en la inhabitación en la persona (CV 19,11). Cuando el ser humano está lleno de amor y comprende por su razón que aún no ama mucho, entonces surge el deseo de la visión. Teresa convoca a la experiencia de la Contemplación. 
El hombre es, al mismo tiempo, un proceso haciéndose en el devenir histórico, que cuenta con la razón y el amor para entender, actualizar y alcanzar la salvación.

Teresa destaca que la razón entiende la salvación de modo paradójico con sus obstáculos y potencialidades. Primeramente hace cinco afirmaciones paradójicas: $1^{\circ}$, la dificultad para ser pobre y atender a las justas y razonables necesidades humanas; $2^{\circ}$, el crecimiento desde la negación de sí y el sufrimiento por el otro; $3^{\circ}$, la paradoja entre el no saber y el querer enseñar; $4^{\circ}$, la razón que no necesita razones, pues sabe que la sed "al saciarse aumenta el deseo de beber"; y $5^{\circ}$, la invitación universal junto al inmerecimiento personal.

Teresa, además, afirma que la salvación se da a través de las capacidades y posibilidades de la razón desplegándose en la oración: $1^{\circ}$ al comprender que lo fundamental está en el Padre Nuestro y en el Ave María; $2^{\circ}$ al admirar que Dios se anonada por el pequeño; y $3^{\circ}$ como un nuevo modelo de relación que Jesús inaugura: ser hijos y hermanos.

En tercer lugar, Teresa se hace cargo de los obstáculos que encuentra la razón para la salvación: uno es la incapacidad de fidelidad a la palabra dada; y junto a este la dificultad de cumplir la voluntad del Padre ante el dolor y la enfermedad; y lo costoso que se le hace al hombre la entrega de la propia libertad. Pero aun así la razón es estimulada por la aspiración a lo definitivo, lo escatológico.

Teresa, contemplando al ser humano en el mundo, dice que el amor actualiza la salvación de Dios en el hombre; esto lo analiza desde la perspectiva del amor humano, el divino y la relación entre ambos. El amor humano lleva a obedecer, es estímulo para el servicio, es predisposición para el bien, y es el fundamento de la vida espiritual. El amor de Dios ayuda a optar por la pobreza; evita la acepción de personas tratando bien a todos; da la libertad para elegir confesores; es desmesura frente al modesto amor humano. Al abordar la relación entre amor humano y divino su referencia es Jesús, en quien encuentra el paradigma, y desde él; urge a la necesidad de configurar el amor humano al de Cristo; invita a la inversión de la lógica respecto al sufrimiento, la gratuidad y la libertad; y a la contemplación del ser humano como misterio de amor y conocimiento.

La relación razón y amor se va liberando en un proceso de reversibilidad. La razón descubre los valores y abre al ser humano a la transcendencia del amor, de ese modo posibilita la opción por la pobreza como una apuesta razonable. La razón detecta y descubre limitaciones y se abre al amor haciendo entrega del don más preciado del ser humano, la libertad. La razón reconoce a Jesús como el mediador entre Dios y el hombre; y el amor aviva el conocimiento, capacitando para la fidelidad. La interacción del amor y la razón es, en definitiva, lo que posibilita la opción por la pobreza, la entrega de la libertad y la fidelidad. Estas opciones acontecen en el cristiano en quien la razón y el amor, conjuntamente, experimentan la Presencia de Dios y configuran al ser humano con Cristo dándole la identidad en su filiación, fraternidad y solidaridad.

Este segundo apartado, en que ha abordado al hombre como ser procesual, lo resuelve apelando al Espíritu Santo que actúa en el mundo situando al hombre bajo la gracia (CV 27, 7). El hombre íntegro se une estrechamente a toda la realidad con lazos de amor. La acción del Espíritu Santo crea el deseo de la Unión. Teresa provoca al seguidor de Jesús a la práctica de la Alabanza. 
El ser humano vive esperanzado en el mundo, porque el amor revela la santidad, la razón la esclarece; y juntos, amor y razón, se plenifican en la santidad.

Teresa va desarrollando en tres pasos cómo el amor revela la santidad. $1^{\circ}$. El amor perfecto es intenso, apasionado y transcendente, y esto se relaciona con la sabiduría y construye el cuerpo de Cristo en este mundo. $2^{\circ}$. El amor de Dios completa al hombre a través del fuego hasta la muerte que es la puerta para la vida definitiva donde el hombre se ABRASA de amor sin entender (CV 25, 2). $3^{\circ}$. Uno de los efectos producidos por el amor de Dios en el hombre, es la creación de un nuevo ser que se manifiesta como persona "enferma de amor" y que sin embargo se entiende y es razonable. Otros efectos son: el resplandecer ante el mundo cuando se descubren cauces de expresión de lo inefable; y que el amor de Dios en el hombre se da a entender a través de la comunicación y de la reverencia filial.

La razón esclarece la santidad, ya que la razón discerniendo y profundizando en lo humano, lo encamina hacia la plenitud: así comprende la kenosis de Dios y las tinieblas humanas, y puede abrirse a una nueva racionalidad que anule los esquemas estratificados. La santidad se esclarece porque la razón anhela la felicidad descubierta en la unión con el Amado. Por ello se hace un camino de gozo en su búsqueda; porque va mirando al cielo, lugar de la presencia definitiva de Dios. Se da la entrega de la libertad y así se da cabida en el ser humano a la presencia de Dios. Y se evita la tentación desde la práctica de la oración y la vida en gracia.

La santidad es para Teresa la plenificación de amor y razón. Primeramente el amor lleva al conocimiento y la razón valora el amor como perfección humana porque atisba signos de la presencia de Dios en el hombre. En esa interrelación se logra la significatividad del cristiano. Un amor tan desmedido como el de Jesús provoca que se eternice y dé lugar a una recompensa impensable. Un amor y un conocimiento de esta envergadura sitúan al hombre en la gracia, esto es, en la plena realización del ser humano. Teresa descubre la plenificación de amor y razón, también al afirmar " ... con tanta razón amamos"; está sugiriendo una apuesta por un amor sabio, un amor con conocimiento. Se conoce al Señor en sus diversas presencias y ahí se le ama: “¡Oh Dios mío, quien no os conoce no os ama!”. Otro aspecto que desarrolla Teresa es que el hombre, que vive en esperanza en el mundo, significa la santidad cuando el amor y la razón se relacionan perijoréticamente. En Dios el amor y el conocimiento están unidos, y en la criatura es una aspiración que en ocasiones acontece (racionalidad amorosa). La presencia de Jesús en el ser humano y en la comunidad es ya anticipo de lo definitivo en este mundo, es la escatología ya cumpliéndose.

Este tercer acápite, que trata la vida humana en esperanza, lo vincula con el espíritu del Señor consumador del ser humano, la historia y toda la creación (CV 38, 1). El espíritu del Señor provoca la consumación de toda la creación. El hombre asumiéndose en su creaturalidad, abierta al creador, llega a la plenitud. El espíritu del Señor guía hasta la perfección, es un proceso a modo de combate, como liberación que el Salvador sigue engendrando en cada uno, en la Iglesia, en el cosmos. Teresa invoca para que cada creyente acceda a la Adoración.

Recapitulando: el querer ver de la razón conduce a la visión de Dios cuando el hombre se deja convocar a la contemplación. El desear que el amor ate, acerca a la 
unión con Dios, si el hombre se deja provocar por su acción y le alaba. La perfección puede llegar a través de la perijoresis de amor y razón cada vez que el hombre invoca a Dios en Adoración. Resulta curioso que estos son los tres pasos que propone Teresa en su "Camino de Perfección", y son los únicos tres puntos de toda la obra en que se menciona al Espíritu. El Espíritu está detrás de la visión, la unión y la perfección. El espíritu de Dios, el Espíritu Santo y el espíritu del Señor. La racionalidad apasionada de Santa Teresa se resuelve en el Espíritu Santo, el evangelio de Juan afirma que el Espíritu Santo que es amor lo enseña todo (Jn 14, 26).

\section{RESUMEN}

Santa Teresa de Ávila es una de las grandes figuras de la mística del Siglo de Oro Español. Pablo VI la declara Doctora de la Iglesia el 27 de septiembre de 1970. Este hecho supone que el puesto y la función de la mujer en la Iglesia quedaron afectados cuando se declaró a Santa Teresa Doctora de la Iglesia.

Camino de Perfección es la primera obra impresa de Santa Teresa, en el año 1583 quiere ser un libro guía para las comunidades. Es un itinerario de conversión recorrido con una determinada "racionalidad apasionada" que desenmascara todo lo que no está al servicio del Reino.

El presente estudio pretende ayudar a detectar la racionalidad teológica de Teresa desde la relación razón y amor en su obra Camino de perfección. En él se comienza a descubrir la propia sistematicidad del pensar de esta autora. Teresa ha ido vertiendo sus ideas respecto a la realidad de todo lo humano. Lo hace de un modo experiencial y sin atenerse, demasiado, a las normas de uso de los grandes conceptos en su época.

\section{ABSTRACT}

St. Theresa of Avila is one of the great figures of the mysticism of the Spanish "Golden Age". Paul VI declared her a Doctor of the Church on September $27^{\text {th }}$, 1970. This fact presupposes that the place and function of women in the Church were influenced when St. Theresa was declared Doctor of the Church.

Road of Perfection is the first printed work of St. Theresa's, in the year 1583, and was intended to be a guide for communities. It is an itinerary of conversion traveled through with a determined "passionate rationality" that unmasks everything not at the service of the Kingdom.

The present study intends to help detect the theological rationality of Theresa from the reason-love relationship in her work Road of Perfection. In it the author's own systematic thought begins to be discovered, depositing her ideas in relation to the reality of all that is human. She does this in an experiential way and without overly depending upon the norms of the period regarding great concepts. 